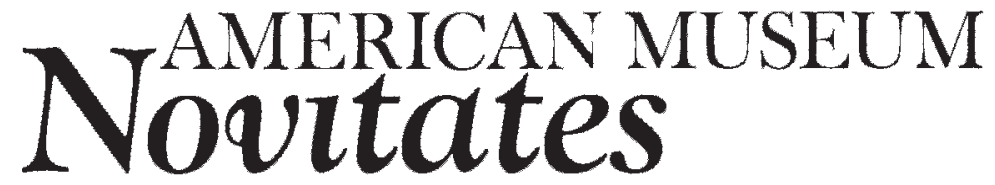

PUBLISHED BY THE AMERICAN MUSEUM OF NATURAL HISTORY CENTRAL PARK WEST AT 79TH STREET, NEW YORK, NY 10024 Number 3660, 31 pp., 15 figures, 3 tables

August 28, 2009

\title{
New Species of Lizards from Auyantepui and La Escalera in the Venezuelan Guayana, with Notes on "Microteiid" Hemipenes (Squamata: Gymnophthalmidae)
}

\author{
CHARLES W. MYERS, ${ }^{1}$ GILSON RIVAS FUENMAYOR, ${ }^{2}$ AND \\ ROBERT C. JADIN ${ }^{3}$
}

\begin{abstract}
Names are provided for two montane gymnophthalmid lizards that have been long known from the Venezuelan Guayana, but that were not described by other workers because specimens had been lost.

Euspondylus auyanensis, new species (= Anadia sp. auctorum), is known only from the summit of Auyantepui, where it was originally discovered by S. Gorzula in 1984; a later specimen, the holotype, was collected by Renaud Boistel in 1998. The monophyly of Euspondylus has not been established and the generic assignment is tentative.

Anadia escalerae, new species, is based on a specimen obtained by John Cadle in 1980, in the region of La Escalera, to the east of Auyantepui. It agrees with Anadia sensu stricto in being a slender attenuate lizard, but is unusual in having weakly keeled (vs. smooth) dorsal scales and in having the prefrontals separated by an azygous scale. The last condition also occurs in the holotype of A. pariaensis from the Península de Paria, about $500 \mathrm{~km} \mathrm{NNW}$ of La Escalera; although differing in several characters, they may be sister species.

A new specimen of the rare Anadia blakei (from Cerro Humo, Península de Paria), is described and illustrated. It is a robust lizard, markedly different in habitus from Anadia sensu stricto.

\footnotetext{
${ }^{1}$ Curator Emeritus, Division of Vertebrate Zoology (Herpetology), American Museum of Natural History.

${ }^{2}$ Museo de Biología, Facultad Experimental de Ciencias, La Universidad del Zulia, Apartado Postal 526, Maracaibo 4011, Maracaibo, Venezuela.

3 Amphibian and Reptile Diversity Research Center, Department of Biology, University of Texas at Arlington, Box 19498, Arlington, TX 76019-0498.
} 
Commentary is provided on the usefulness of hemipenial data in gymnophthalmid systematics. The hemipenes of Euspondylus auyanensis, Anadia blakei, and A. ocellata are described and illustrated. The Guayana endemic genus Adercosaurus is provisionally assigned to the subfamily Alopoglossinae based on hemipenial and other resemblances to Ptychoglossus.

\section{RESUMEN}

Se describen dos lagartos gymnophthamidos montanos conocidos por largo tiempo de la Guayana Venezolana, pero los cuales no habían sido descritos formalmente debido a que los primeros ejemplares fueron extraviados.

Euspondylus auyanensis, nueva especie (= Anadia sp. auctorum), es conocida únicamente de la cima del Auyantepui, donde fue originalmente descubierta por Stephan Gorzula en 1984; un ejemplar recolectado posteriormente por Renaud Boistel en 1998, es utilizado para describir la especie. La monofilia de Euspondylus no ha sido establecida y la asignación de la especie en este género es tentativa.

Anadia escalerae, nueva especie, es descrita con base en un ejemplar obtenido por John Cadle en 1980, en la región de La Escalera, al este del Auyantepui. Esta concuerda con el genero Anadia sensu stricto en ser un lagarto atenuadamente alargado, pero inusualmente posee escamas dorsales quilladas y las prefrontales separadas por una escama sencilla. Esta ultima condición también esta presente en el holotipo de $A$. pariaensis de la Península de Paria, a unos $500 \mathrm{~km}$ NNW de La Escalera; aunque estas dos especies difieren en varios caracteres, podrían tratarse de especies hermanas.

Un nuevo ejemplar de Anadia blakei (proveniente de Cerro Humo, Península de Paria), es descrito e ilustrado. Esta es una especie robusta, marcadamente diferente en corpulencia de las demás especies de Anadia sensu stricto.

Finalmente, se comenta sobre la importancia de la morfología de los hemipenes en la sistemática de gymnophthalmidos. Los hemipenes de Euspondylus auyanensis, Anadia blakei, y Anadia ocellata son descritos e ilustrados. El genero Guayanes, Adercosaurus, es provisionalmente asignado a la subfamilia Alopoglossinae basado en su hemipene y otras semejanzas con Ptychoglossus.

\section{INTRODUCTION}

The small lizards known for many years as "microteiids" were formerly placed in the family Teiidae along with their larger relatives, the "macroteiids." Most workers considered them monophyletic (see especially Harris, 1985), although one microteiid specialist (Presch, 1983) argued that they were not monophyletic and suggested that microteiids were closer to Old World lacertids. The microand macroteiids sometimes were placed in separate subfamilies, a pragmatic approach except that there was no convincing evidence that the microteiids themselves comprise a single monophyletic group. Nonetheless, without challenging a close relationship between macroteiids and microteiids or the synapomorphies identified by Harris (1985), there was a subsequent social trend among systematists to place them in separate families. The situation was reviewed by Myers and Donnelly (2001: 48-49), who rejected uncor- roborated authoritarianism and who were perhaps the last authors to place newly discovered microteiids in the family Teiidae.

About the same time, however, Pellegrino et al. (2001) published a major reclassification of microteiids based on mitochondrial and nuclear DNA from 50 species in 26 genera. This was a breakthrough study that provided reasonably strong support for microteiid monophyly - previously suggested mainly by small size and a single unequivocal morphological character (anterior nasal scales separated by one or two frontonasals; Boulenger, 1885). Castoe et al. (2004) re-evaluated the new classification, providing corrections and new data without weakening the support for monophyly of a family Gymnophthalmidae (or subfamily Gymnophthalminae, a subjective choice).

Despite the advances, however, microteiid (gymnophthalmid) taxonomy remains difficult to approach owing to the large number of genera (some poorly defined) and many rare 
species. We add two species to the group in this paper, including one of uncertain generic status. These are not, however, recently discovered lizards; both are known species that have remained unnamed for over a quarter of a century. As indicated by Gorzula (1992: 276; also Gorzula and Señaris, 1999: 115), these species were to have been named by Gorzula and Alfredo Paolillo, but museum specimens on loan were misplaced or lost. A specimen of each species is now available and names and basic descriptions can finally be provided. We also take opportunity to comment on the use of hemipenial data in gymnophthalmid classification.

\section{Euspondylus auyanensis, new species}

Figures 1-7

Anadia species: Gorzula (1992: 276). Ayarzagüena et al. (1992: 127). Myers (1997: 4). Mentions of an undescribed species discovered by Gorzula on Auyantepui. Anadia species b: Gorzula and Señaris (1999: 115-117), brief description of Gorzula's lost specimens from Auyantepui.

Anadia species: Myers and Donnelly (2008: 88-89), discussion of foregoing report and in-press mention of rediscovery of species by Renaud Boistel.

Holotype: Muséum National d'Histoire Naturelle (MNHN) 1999.4799, an adult male from the summit of Auyantepui, [near] "El Libertador,"4 2325 m, Estado Bolívar, Venezuela, collected by Renaud Boistel in November or December, 1998.

Etymology: From the tepui Auyán + -ensis (-e), a Latin adjectival suffix indicating origin or place.

Definition And Diagnosis: A small lizard (adult $\delta 60 \mathrm{~mm}$ SVL) of moderate build; tail less than twice body length. Tongue bearing imbricate scalelike papillae; numerous pairs of chevron-shaped infralingual plicae. Hemipenis bilobed, with chevron-shaped folds bearing comblike rows of spinules.

\footnotetext{
4 "El Libertador" refers to a bust of Simón Bolivar, which was placed near the southern edge of the Auyán summit in 1956, by an expedition from the Universidad Central de Venezuela (Lindorf, 2006: nt. 18). It is a wellknown place name that is shown on maps in Dunsterville (1965) and Steyermark (1967); see Myers and Donnelly (2008: 27).
}

Head scales smooth. Paired prefrontals present. Supraoculars separated from eyelids by a complete superciliary series; anterior superciliary large, sometimes expanded dorsally to fuse with small presupraocular. Interparietal extending farther posteriad than parietals. Nasal scales separated by rostral and undivided frontonasal. Loreal large, in contact with supralabial; frenocular absent(?), seemingly fused with loreal (but see comment under Remarks). Lower eyelid with a row of about six somewhat enlarged, semitranslucent palpebrals. Tympanum recessed, lightly pigmented. Single postmental scale followed by two pairs of genials in contact with labials; genials followed by large medially separated postgenials. No anterior gular crease at ears and no guttural fold across throat; collar fold conspicuous. No enlarged paramedian gulars.

Dorsal scales keeled, rectangular or slightly rounded posteriorly, in transverse rows only. Lateral scales small, smooth; lateral fold absent. Ventrals smooth, rectangular, subimbricate, forming both transverse and longitudinal rows. Preanal scales in two rows. Femoral pores and preanal pores on same line. Limbs pentadactyl, all digits clawed; subdigital lamellae mostly single; base of pollex with a weakly enlarged thenar scale. Dorsal and lateral caudal scales rectangular, keeled only on base of tail, smooth distally. Subcaudals smooth, wider than dorsal caudals, disposed in two rows of large squarish scales distally. Caudal scales in transverse rows one-scale wide all around tail; dorsal caudals in transverse rows only, ventral caudals in both transverse and longitudinal rows.

The generic affinities of "Euspondylus" auyanensis are uncertain, but the combined characters above and the distinctive coloration (figs. 1, 3) separate it from all other named microteiids. It also is a larger lizard than other Venezuelan species currently assigned to Euspondylus. See Comparisons.

\section{DesCription OF Holotype}

The undissected male holotype is about $152 \mathrm{~mm}$ in total length $(59.6 \mathrm{~mm} \mathrm{SVL} \mathrm{+}$ $92 \mathrm{~mm}$ tail length [tip missing]). It is sexually mature as judged by the well-developed hemipenes and swollen femoral pores. 


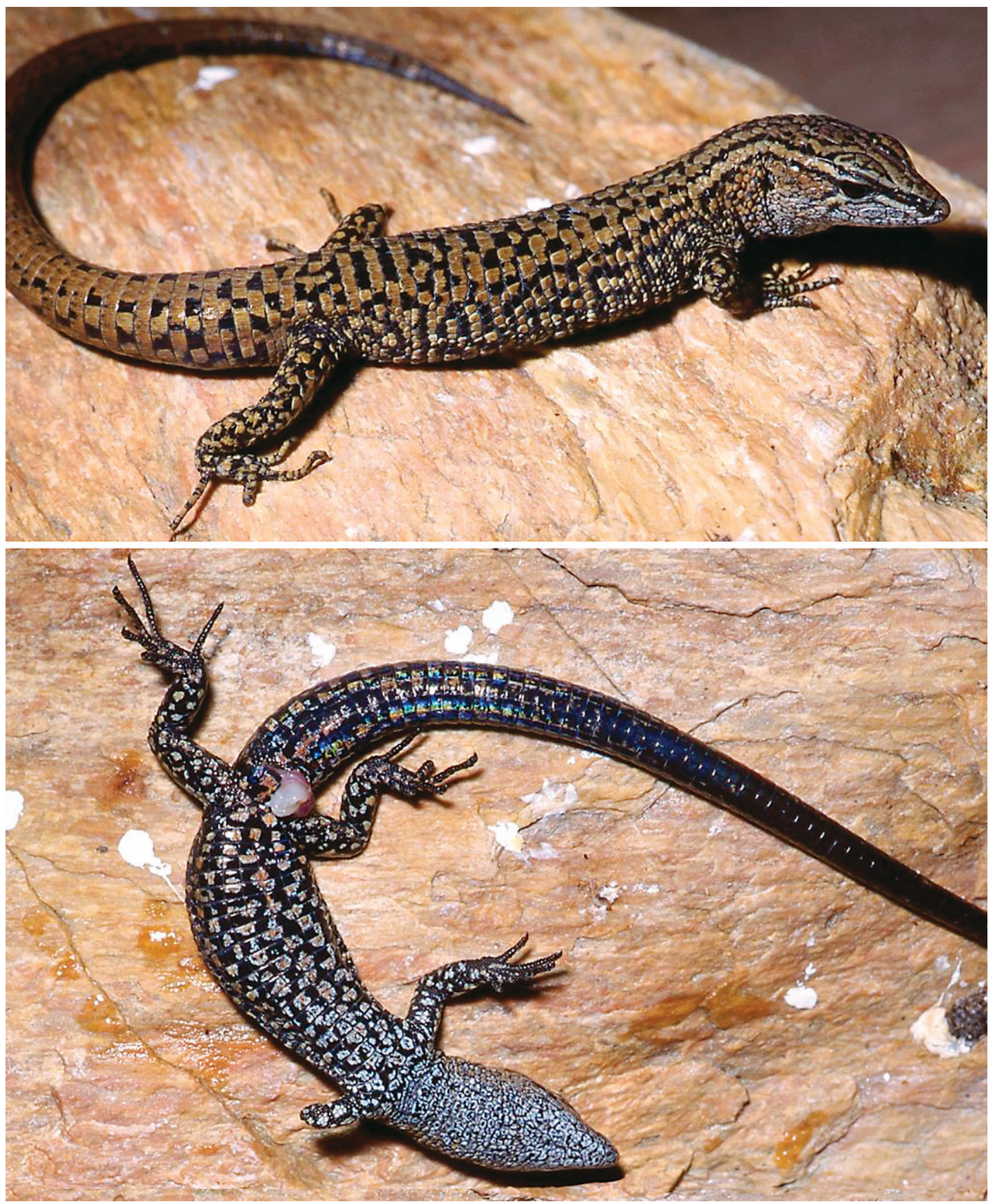

Fig. 1. Euspondylus auyanensis, new species. The male holotype (MNHN 1999.4799) in life. (Photograph by J.-C. de Massary). 

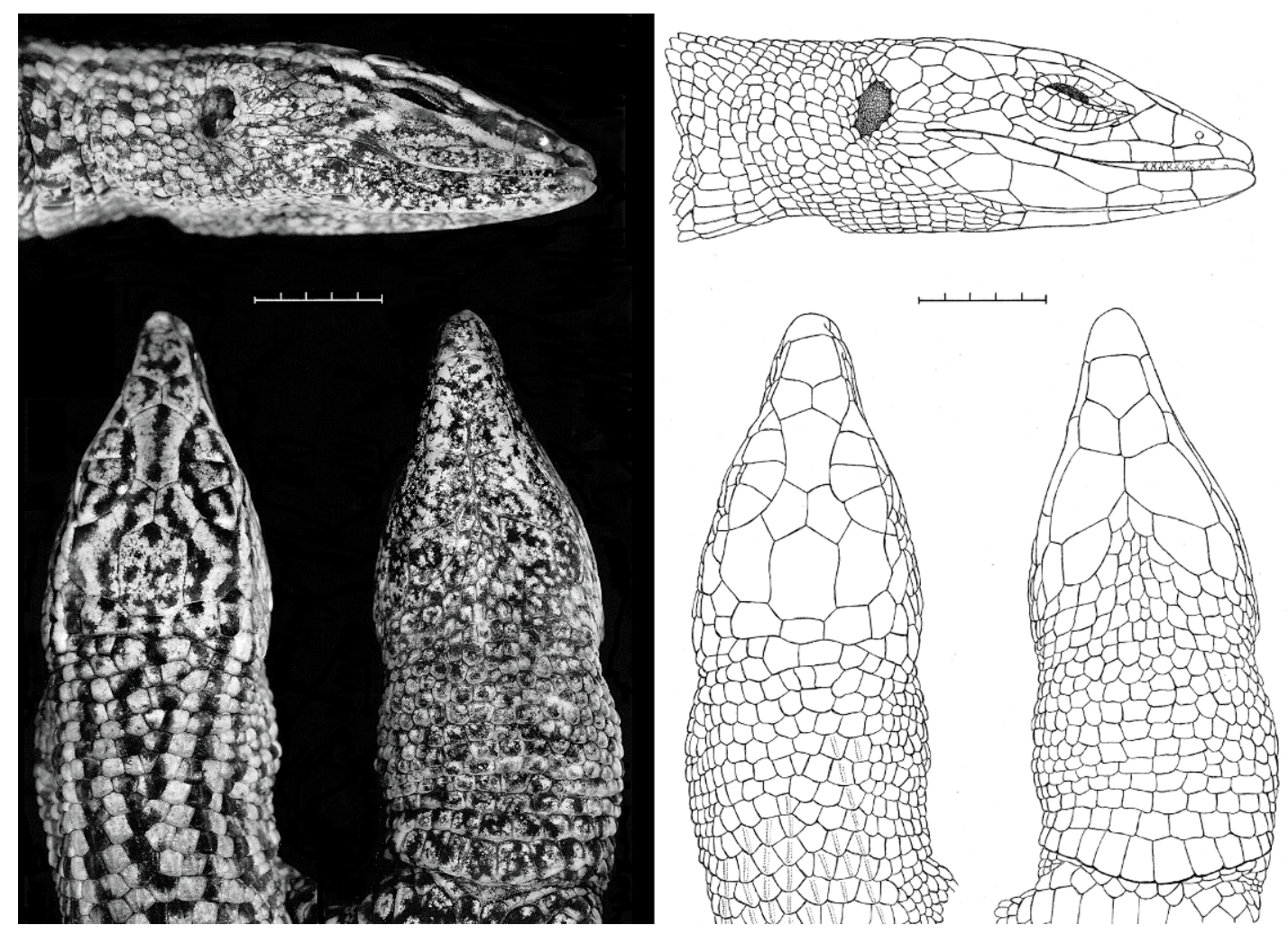

Fig. 2. Euspondylus auyanensis, new species. Lateral, dorsal, and ventral views of head of holotype $($ MNHN 1999.4799). Scale lines $=5 \mathrm{~mm}$.

Measurements, some scale counts, and relevant methodology are provided in table 1.

Habitus AND Proportions (Figs. 1-3): Snout attenuate, not flat on top. Head length $24 \%$ of SVL, 1.6 times longer than wide, 1.3 times wider than high; head little wider than neck (which is slightly overinflated with preservative). Neck long, $63 \%$ of head length, $33 \%$ of trunk length. Snout-axilla length 104\% of trunk length, $47 \%$ of SVL. Body wider than deep. Tail ventrally flattened proximally, otherwise nearly cylindrical. Limbs pentadactyl, all digits clawed (lacking left forelimb). Forelimb $30 \%$ of SVL, 67\% of trunk length; hind leg equal to trunk length, $45 \%$ of SVL; appressed limbs widely overlapping (toe IV extending past elbow).

Tongue And Dentition: (To avoid damage to the unique specimen, the mouth was gently pried only partly open, allowing minimal description.) Tongue lanceolate; gray over visible dorsal surface well onto fork (tips unpigmented); except for tips, fork also gray below; rest of visible tongue nearly unpigmented ventrally. Upper surface of tongue behind fork covered with scalelike papillae (proximal part of tongue not examined), which extend onto ventrolateral sides of tongue; papillae not arranged in rows. Raised medioventral side of tongue with median groove, which extends anteriorly through numerous pairs of thin, oblique, anteriorly converging (chevronlike) infralingual plicae; anterior pair of infralingual plicae much larger than those following.

Anterior maxillary and dentary teeth nearly conical in profile; anterior teeth slightly recurved, losing curvature and becoming slightly larger and weakly bicuspid posteriorly (with a very small cusp on anterior face of tooth).

Scutellation: All head scales smooth. Rostral plate much wider than deep, laterally in contact with nasal and first supralabial, dorsally in contact with large frontonasal. 


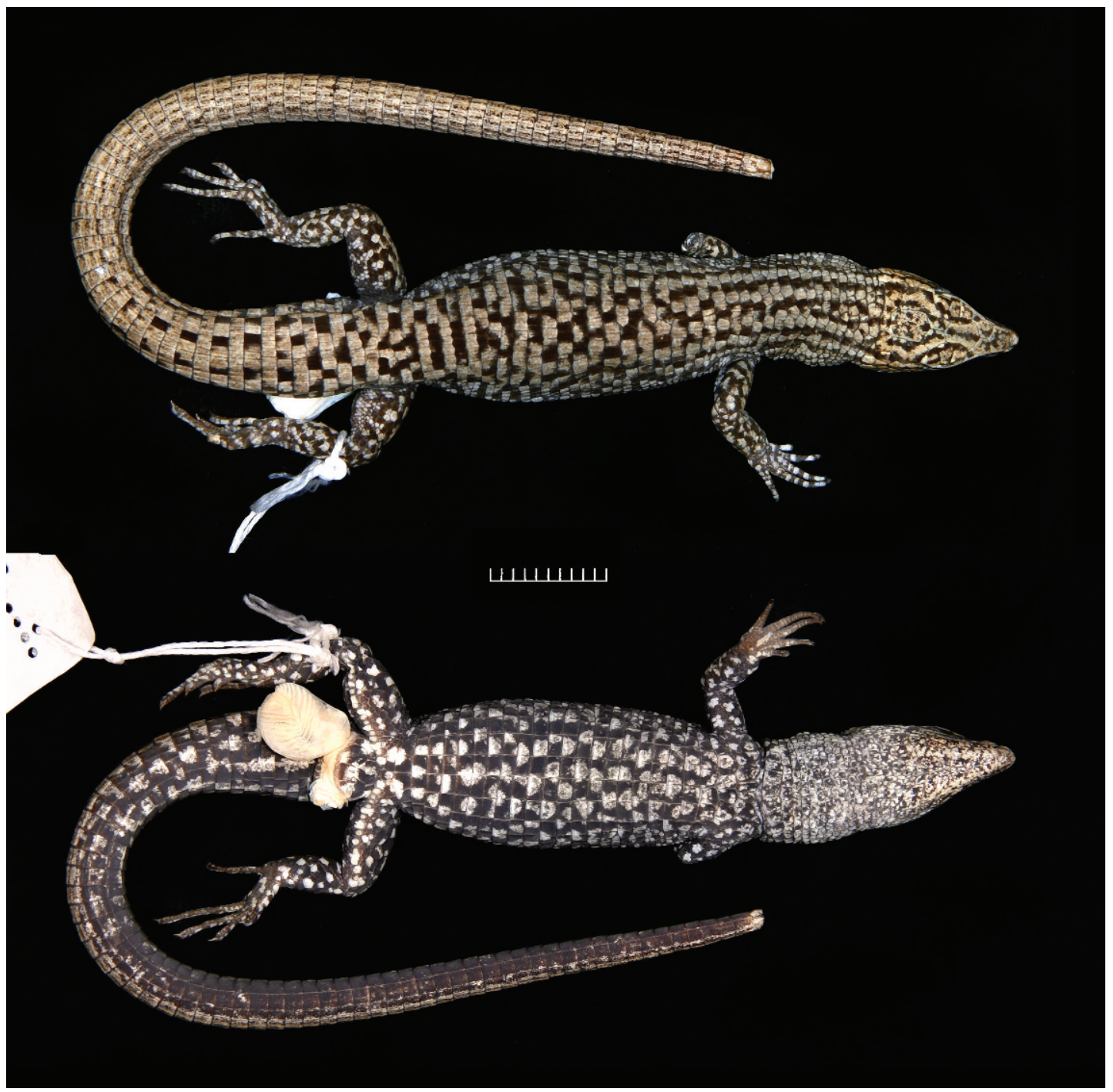

Fig. 3. Euspondylus auyanensis, new species. Dorsal, and ventral views of holotype, showing habitus and color pattern in preservative. Scale line $=10 \mathrm{~mm}$.

Frontonasal pentagonal, with nearly straight anterior edge and apex on posterior edge. Paired prefrontals in broad contact medially. Frontal weakly hexagonal, concave laterally. Paired frontoparietals with long medial suture, in contact with interparietal, parietals, and two posterior supraoculars. Three or four large supraoculars: three supraoculars on left side preceded by a small presupraocular; four supraoculars on right side resulting from apparent fusion of presupraocular with the first superciliary (or "presuperciliary"). Interparietal longer than wide, with anterior apex, weakly concave posteriorly. Parietals not as wide as interparietal, not extending as far posteriad as interparietal. Three dorsal occipitals (postparietals), the medial one smallest. Two postoccipitals larger than other dorsal neck scales.

Nostril slightly anterior of center in nasal scale, which is divided below naris on right side only. Nasal scale in broad contact with rostral anteriorly and with loreal posteriorly. Loreal large, situated between a prefrontal and second supralabial, posterodorsally in 


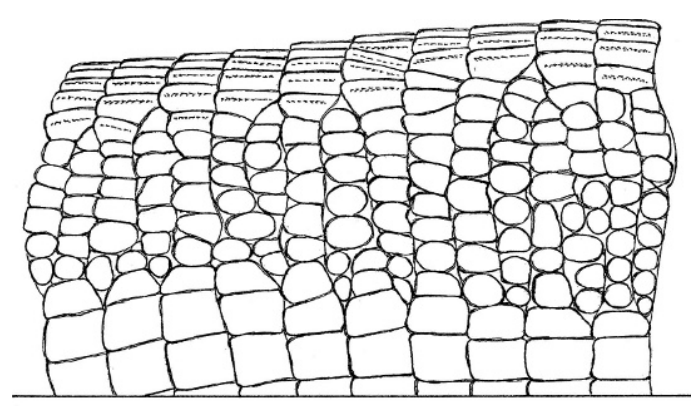

Fig. 4. Euspondylus auyanensis, new species. Trunk of holotype in lateral view (head to right), showing scalation at midbody, $\times 4$.6. Small lateral scales are smooth and juxtaposed, contrasted to the larger keeled, weakly imbricate dorsals and stilllarger smooth, subimbricate ventrals. Scale line $=$ $1 \mathrm{~mm}$.

broad contact with first superciliary. Frenocular absent (seemingly fused with loreal, but see under Remarks). One preocular and several irregular postoculars. Two (left) or three elongate superciliaries posterior to large first superciliary; one (right) or two small azygous scales inserted between superciliaries and penultimate supraocular. A very elongate subocular, smoothly (without pronounced angularity) approaching lip above suprala- bials 4-5, which are very low and in little more than point contact. Seven supralabials on each side (posteriormost very small).

Eight large ciliaries along upper eyelid; about 6 smaller ciliaries along edge of lower eyelid. Edges of eyelids darkly pigmented, brown pigmentation on eyelids otherwise sparse. Semitranslucent scales on lower eyelid include a line of 4-7 somewhat enlarged palpebrals below ciliaries; lower palpebral granules concealed by folding.

Temporal scales juxtaposed, smooth, with rounded surfaces, largest above, progressively smaller ventrad. Ear opening a vertical ovoid, edged all around with pebblelike granular scales; tympanum recessed, lightly pigmented.

Underside of head with four infralabials on each side. Large mental followed by large postmental in lateral contact with first infralabials. Two pairs of genials, each pair in median contact, in contact with infralabials $1-$ 3 laterally. Two pairs of side-by-side, large postgenials, each pair in contact with a member of the second pair of genials; lateral member of each pair of postgenials in partial contact with third infralabial. Small to medium-size gular scales with slightly rounded surfaces, subimbricate. Gulars posteriorly becoming larger and arranged in transverse

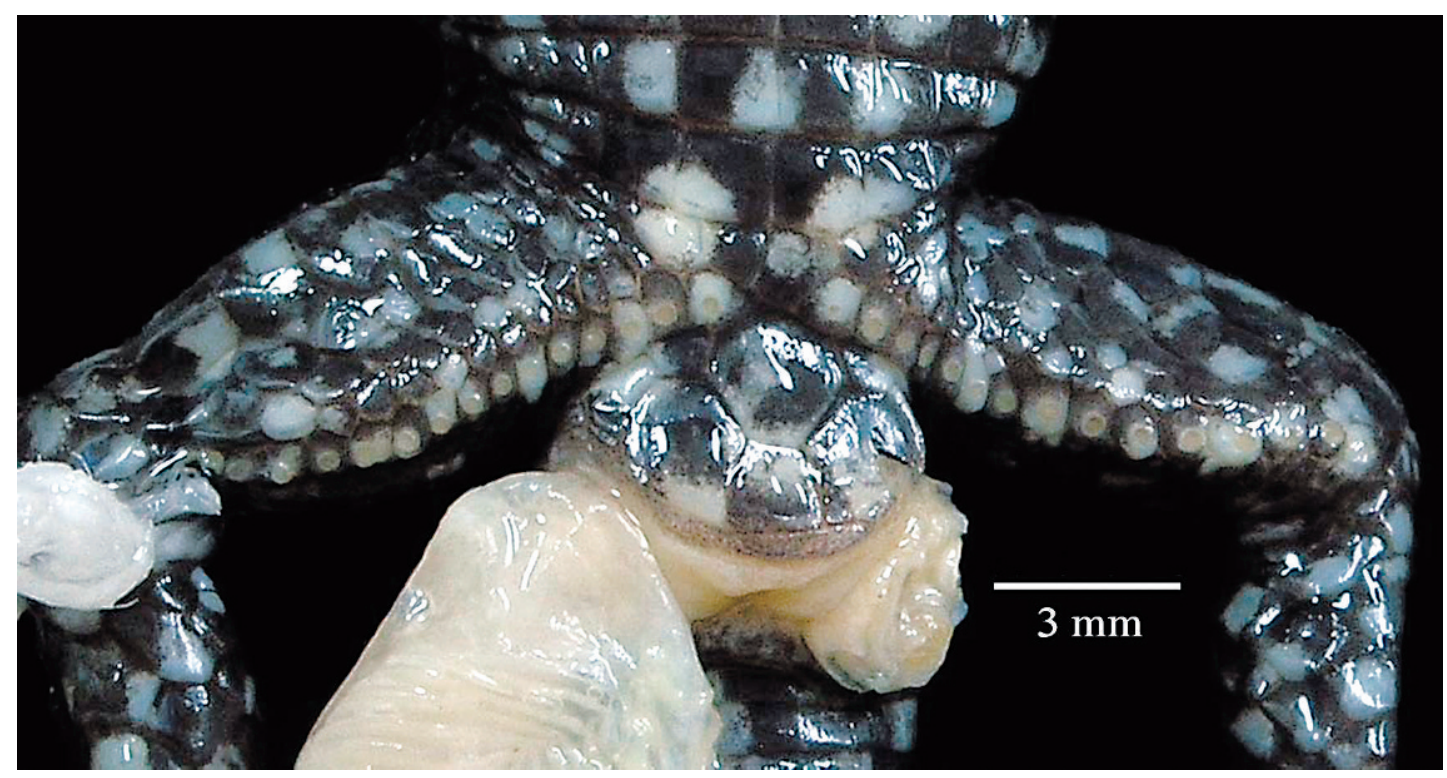

Fig. 5. Euspondylus auyanensis, new species. Subpelvic region of holotype, showing preanal scales and large femoral pores. (Photograph by R. C. Jadin). 


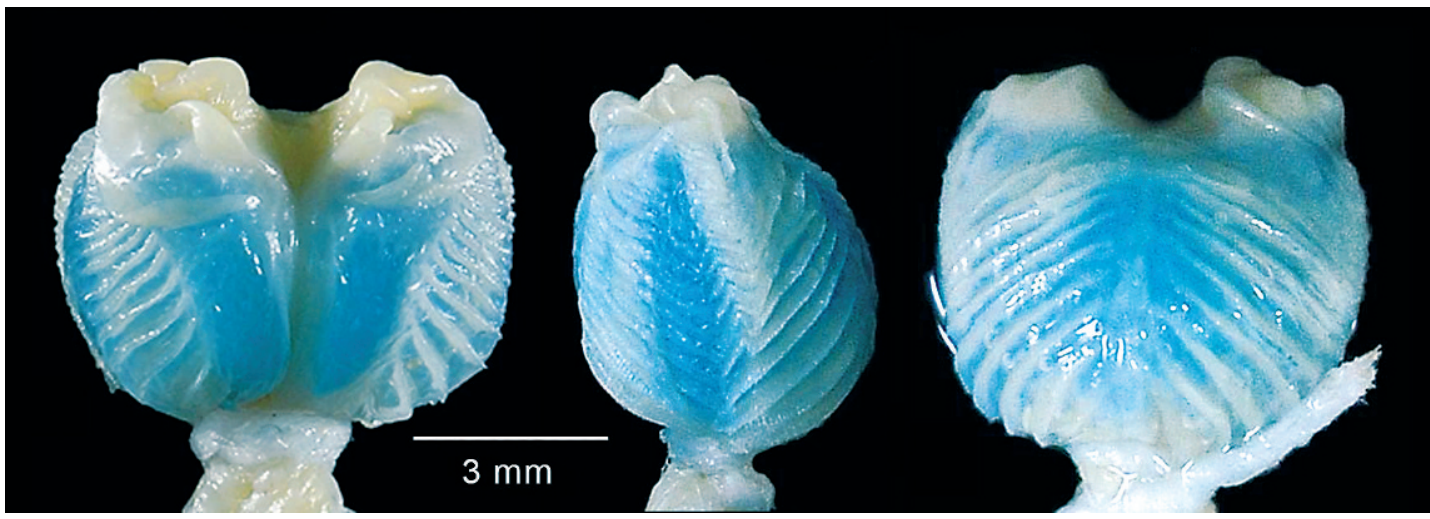

Fig. 6. Euspondylus auyanensis, new species. The left everted hemipenis of holotype. Left: sulcate side. Center: lateral view, turned with sulcate side facing to left. Right: asulcate side. (Photographs by R. C. Jadin).

rows, culminating in collar row of about eight scales. Medial collar scales largest, overhanging collar fold of small scales. Side of neck between ear and collar pebbled with subequal, rounded juxtaposed scales.

Dorsal scales on neck subimbricate, irregularly shaped to posteriorly rounded, some become weakly keeled toward forearms. Dorsal body scales keeled, weakly imbricate, longer than wide - rectangular or with slightly rounded posterior ends - in transverse rows only. About 10 large keeled scales across

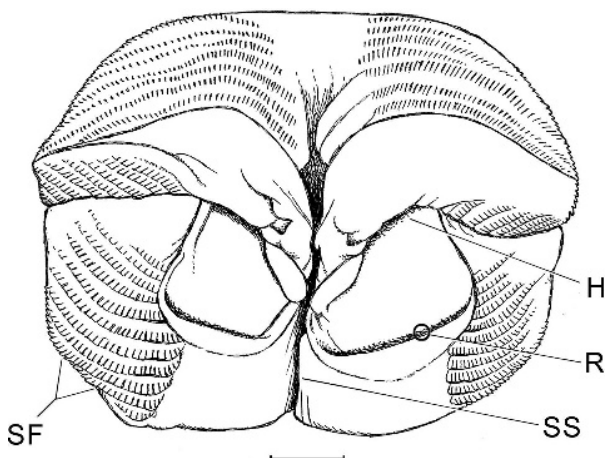

Fig. 7. Euspondylus auyanensis, new species. Apical view of the right everted (in situ) hemipenis of the holotype, showing complex folding of tissue. The two lobes are more closely appressed than in the left organ (fig. 6), probably because of maximal inflation pressure coupled with tension in the major retractor muscle. The following structures also are visible in figure 6 (left side): $\mathrm{H}$, "hood;" $\mathrm{R}$, rim of collar around "basin" (for impeding flow of seminal fluid?); SF, spinulate flounces; SS, sulcus spermaticus (distal branches not visible). Scale line $=1 \mathrm{~mm}$. transverse rows at midbody, each transverse row of dorsals laterally becoming 1-2 rows of much smaller scales (fig. 4); the small lateral scales are smooth and juxtaposed.

Ventral scales smooth, quadrangular, roughly 1.3-1.6 times wider than long, barely subimbricate; in 9-10 longitudinal rows at midbody (including 1-2 small ventrolateral plates) and 24 transverse rows between collar and preanal scales. Ventrals much wider than dorsals.

Three anterior preanal scales, the median one much larger than the lateral ones (fig. 5). Five marginal preanal scales anterior to vent, the three middle ones much larger than the lateral ones. Adult male with 15/18 femoralpreanal pores; pore scales slightly swollen, in contact, forming an uninterrupted series from each leg onto preanal area, where the left and right sides are separated by one poreless scale.

Dorsal and lateral caudal scales rectangularly longer than wide, strongly to weakly keeled on base of tail and smooth distally. Subcaudals smooth, about same length as dorsals but larger, and wider than long on base of tail, becoming disposed in two rows of large squarish scales distally. All caudal scales subimbricate, with straight edges, in transverse rows one-scale wide all around tail, the first few rows ventrally narrowed behind vent.

Dorsal surfaces of arm with large, smooth imbricate scales, obtusely pointed on upper arm, tending to have broadly rounded edges on lower arm. Ventral side of upper arm with small, smooth, rounded subimbricate scales; ventral side of lower arm with large rounded or obtusely pointed, smooth imbricate scales. 
TABLE 1

Measurements (in mm) and Scale Counts of Holotype of Euspondylus auyanensis, New Species

\begin{tabular}{|c|c|}
\hline Specimen & MNHN 1999.4799 ad. $\hat{\sigma}$ \\
\hline Snout-vent length (SVL) & 59.6 \\
\hline Tail length & $92+$ \\
\hline Head length (oblique, snout-ear) & 14.2 \\
\hline Greatest head width & 8.8 \\
\hline Greatest head depth & 6.6 \\
\hline Snout-axilla Length & 28 \\
\hline Neck length ${ }^{\mathrm{a}}$ & 9 \\
\hline Trunk (axilla to groin) & 27 \\
\hline Forelimb length ${ }^{\mathrm{b}}$ & 18 \\
\hline Hind limb length ${ }^{\mathrm{b}}$ & 27 \\
\hline Subdigital lamellae finger IV & 14 \\
\hline Subdigital lamellae toe IV & 19 \\
\hline Middorsal scales ${ }^{c}$ & 41 \\
\hline Ventrals, longitudinal rows ${ }^{\mathrm{d}}$ & 9 \\
\hline Ventrals, transverse rows ${ }^{\mathrm{e}}$ & 24 \\
\hline Scales around midbody ${ }^{\mathrm{f}}$ & 32 \\
\hline Supralabials & 7 \\
\hline Infralabials & 4 \\
\hline
\end{tabular}

${ }^{\mathrm{a}}$ Length of neck from posterior edge of ear to forearm held at right angle to body.

${ }^{b}$ Limb length measured from axilla or groin to tip of claw of longest digit.

${ }^{\mathrm{c}}$ Middorsal scales counted from postoccipitals to level of posterior edge of thigh held at right angle to body.

${ }^{\mathrm{d}}$ Longitudinal ventral rows counted at midbody (transverse ventral row 12) and including 1-2 small ventrolaterally positioned plates.

${ }^{\mathrm{e}}$ Transverse rows of ventrals counted between collar and pair of anterior preanals.

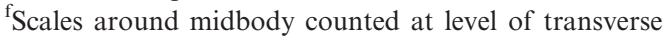
ventral row 12 .

Hind limbs with large, mostly obtusely pointed imbricate scales that are weakly striated or keeled dorsally and smooth ventrally. Posterior and posterodorsal surfaces of thigh pebbled with small, round, and raised juxtaposed scales.

Small to moderately large scales atop hands and feet. Supradigital scales single; upper and lower ungual-sheath scales covering base of claws, leaving tips well exposed. Palms and soles with small juxtaposed scales (possibly raised but too desiccated to verify for certain). A weakly enlarged thenar scale, with slightly produced inner edge, on inner margin of palm at base of pollex. Subdigital lamellae mostly single, but a few divided at bases of digits. Longest (4th) finger with 14 subdigital lamellae, longest (4th) toe with 19 subdigital lamellae.
Coloration: In life (fig. 1), brown above with irregularly distributed squarish black markings occupying single scales. A black stripe from snout to eye; a pale brown blackedged light stripe from eye to shoulder. Underside of head bluish gray with dark speckling; venter and undersides of limbs mottled black and pale bluish gray, with slight tinges of orange on belly and base of tail; black pigmentation increasing onto base of tail, becoming solid black posteriorly. All pattern elements of the holotype well retained in preservative (figs. 2-3), with ground color a duller light brown above, grayish below.

Hemipenis: The genitalia of the holotype had been everted during preservation. The attached, fully everted right hemipenis is $8 \mathrm{~mm}$ long and $6 \mathrm{~mm}$ across its widest point; the appressed organ extends to the suture between the sixth and seventh transverse rows of caudal scales. The left organ was detached by Jadin and inflated with blue-dyed petroleum jelly to provide contrast (fig. 6). The right organ subsequently was inflated in situ and illustrated in apical view without removal from the specimen (fig. 7).

The broad hemipenis, tapered near the base, is weakly and symmetrically bilobed. The sulcus spermaticus curves halfway around the base of the organ before running a medial course, which is flanked by a broad nude area on each side (fig. 6, left). The sulcus extends into the center of the crotch to a raised wedge of tissue, where the sulcus bifurcates inconspicuously and centripetally, with a broad indefinite "branch" on the medial side of each lobe (the branches are ill defined).

The base of the hemipenis is nude (obscured by knotted thread in fig. 6). About 12-13 chevron-shaped pairs of oblique plicae or flounces occupy most of the asulcate side, the members of a pair failing to meet at the midline (fig. 6, right). The several basal pairs of plicae are very short. The plicae bear comblike rows of minute mineralized spinules that project slightly from the edges of the plicae and increase in size towards proximal ends of the plicae; the spinules are largest in the short basal plicae, where the terminal ones attain approximately $0.25-0.3 \mathrm{~mm}$ in length.

There are widely separated pairs of oblique plicae on the sulcate face of the hemipenis 
(fig. 6, left), also with comblike rows of spinules. The proximal and middle sulcateside plicae extend weakly around the sides of the organ to connect with the pronounced plicae on the asulcate sides (fig. 6, center).

The apices of the hemipenial lobes show a complex but symmetrical configuration of folded tissue (fig. 7). A transverse fold from the asulcate face of each lobe gives the appearance of a low hood lying across each head. A circular bare space in front of each "hood" is rimmed below by a collar of thin tissue rising from the upper sulcate side of the organ-possibly a shallow basin for concentrating seminal fluid. A facing pair of flaps extend mediad from the circular bare space, to overlap the lobular cleft. Concealed deep on the medial sides of the lobes, part of each broad "branch" of the sulcus spermaticus disappears distally under a fold of tissue. ${ }^{5}$

\section{COMPARISONS}

Euspondylus auyanensis is a distinctive lizard that is assignable to the subfamily Cercosaurinae sensu Castoe et al. (2004); these authors recognized four additional subfamilies in their classification of Gymnophthalmidae. The presence of rows of hemipenial spinules and posteriorly convex parietal-interparietal margin distinguish E. auyanensis from the Alopoglossinae; movable eyelids from the Gymnophthalminae; external ear openings from the Rhachisaurinae; and rectangular dorsal scales and heterogeneous lateral scales distinguish it from the Ecpleopinae.

Within the Cercosaurinae, Euspondylus auyanensis is not easily placed to genus. In general physiognomy, it bears resemblance to species of Euspondylus and Riama (formerly Proctoporus in part; see Doan and Castoe, 2005). However, Riama (as well as Petracola and some Pholidobolus spp.) is distinguished by absence of prefrontal scales, evidently a

\footnotetext{
${ }^{5}$ It seemed possible, but could not be demonstrated by probing or minimal dissection, that there might be a route for seminal fluid to flow under the folding and emerge from under the "hoods" onto the bare spaces confined by collars of tissue. In any case, the facing sides of the bare spaces extend narrowly under the facing flaps to the upper medial surfaces of the lobes. From there, the collared bare spaces seem likely to collect and concentrate seminal fluid on the apices of the everted lobes.
}

constant character in that genus (Doan and Castoe, 2005: 411). Euspondylus, on the other hand is not readily diagnosed, as pointed out by Uzzell (1973: 4):

The genus Euspondylus, although one of the earliest names in Group II [=Gymnophthalmidae in part] (Boulenger, 1885) of the family Teiidae, remains one of the most ill defined, largely because the type species of the genus, Euspondylus maculatus Tschudi (1845), is essentially devoid of unusual external morphological features on which a generic concept could be founded. As a result Euspondylus became a wastebasket.

The above tradition continues with our assignment of the new species to Euspondylus, a genus badly in need of revision.

The male holotype of Euspondylus auyanensis was compared directly with a larger female specimen of the generic type species, Euspondylus maculatus (AMNH R-1704, $75 \mathrm{~mm}$ SVL, from "Juliaca, Lake Aracona, $16,600 \mathrm{ft} ., " 6$ Peru). There are no essential resemblances in color pattern, but tongue

\footnotetext{
${ }^{6}$ This locality is cited in both old and recent literature on the basis of AMNH catalogue entries. Because of the high elevation $(>5000 \mathrm{~m})$, some authors have speculated that it is an erroneous locality for AMNH amphibians, reptiles, birds, and mammals collected by H.H. Keays. Former AMNH Research Associate and Peruvian authority Harvey Bassler (1883-1950) suggested to E.R. Dunn that material labeled Juliaca had probably been collected at about $3000 \mathrm{ft}$. [ $\sim 900 \mathrm{~m}$ ] in the vicinity of Inca Mine, near Santo Domingo, Puno. See Dunn (1942: 459); also Uzzell (1970: 26; 1973: 31, 57-58). AMNH ornithologist John Zimmer (1889-1957) was of the same opinion (fide Vaurie, 1972: 19; Stephens and Traylor, 1983: 103).

However, generally forgotten was the fact that Keays himself had cleared up the confusion in a letter to AMNH mammalogist Joel A. Allen (1838-1921): According to Allen (1901: 41) "Mr. Keays's post-office address was Juliaca ... In a later letter Mr. Keays informs me that the Inca Mines are situated about 200 miles northeast of Juliaca, on the east side of the Andes, on the Inambary River [=Río Inambari], a tributary of the Amazon, and at much lower altitude than Juliaca. The altitude and geographical position were correctly given in the former paper, but in place of Juliaca ... read Inca Mines". Keays had earlier given the elevation as $6000 \mathrm{ft}$. and coordinates $13^{\circ} 30^{\prime} \mathrm{S}, 70^{\circ} \mathrm{W}$, in country "very broken, with deep narrow canons ... covered with a dense undergrowth of shrubs and vines, with here or there a palmetto or a cedar rising above the surrounding vegetation" (Allen, 1900: 219). The locality can be properly cited as 'Inca Mines, Río Inambari, 6000 ft. [1829 m], 1330' S, $70^{\circ} \mathrm{W}$, Puno, Peru.
} 
morphology, general physiognomy, and scutellation are similar. Both specimens have the lateral body scales much smaller than the dorsals, with most of the transverse rows of dorsal scales laterally splitting into two rows of small scales. There are, however, differences worth noting: The specimen of $E$. maculatus has, in addition to the collar fold, an anterior gular crease between the ears and a weak gular fold across the throat; the frenocular is clearly present (not fused with loreal); the dorsal scales are striated and lack median keels.

Mijares-Urrutia et al. (2000) reviewed the two Venezuelan species that are still assigned to Euspondylus, namely E. acutirostris and their new E. monsfumus. These are cloudforest lizards of the Cordillera de la Costa, with the eastern monsfumus known only from Cerro El Humo in the Península de Paria. Mijares-Urrutia et al. (2000) gave an LRC (SVL) length of $46.0 \mathrm{~mm}$ for the female holotype of E. monsfumus; SVL lengths for E. acutirostris were given as:

Males: 44.6 2 2.5 (41.9-49.0 mm), $n=7$

Females: $48.2 \pm 3.89(43.8-53.5 \mathrm{~mm}), n=5$

Euspondylus acutirostris and E. monsfumus are noticeably smaller and more slender lizards than the female specimen of E. maculatus (75 mm SVL) or the male holotype of $E$. auyanensis $(59.6 \mathrm{~mm}$ SVL, $152 \mathrm{~mm}$ total length).

The unique specimen of E. auyanensis was compared with a small series of E. acutirostris from Rancho Grande in northwestern Venezuela (AMNH R-137247, 137254 137259); the series includes an apparently adult female smaller than the range for females given above (AMNH R-137257, $39 \mathrm{~mm}$ SVL, about $115 \mathrm{~mm}$ total length). The color pattern of E. acutirostris is rather variable: a middorsal line of dark pigment, a vivid pale dorsolateral line, and lateral ocelli on the dark flanks are characters that are variably present or absent; the usually pale venter sometimes is suffused with dusky pigment, but it lacks bold black markings.

Size, habitus, and color pattern differences notwithstanding, E. auyanensis is conceivably congeneric with Venezuelan E. acutirostris and the similar E. monsfumus. Scutellation is generally similar, although acutirostris has a pair of large postparietals behind the interparietal, lacks the enlarged postgenials of auyanensis, and has a definite frenocular. These Venezuelan species differ from the specimen of E. maculatus in lacking both the anterior gular crease between the ears and the weak gular fold anterior to the gular collar (characters of uncertain significance at the moment). Montero et al. (2002) posited that Euspondylus acutirostris is closely related to Anadia sensu lato, showing $E$. acutirostris in a clade bordered by Anadia spp. ${ }^{7}$

Euspondylus auyanensis has been referred to as "Anadia sp.," but the lateral zone of small body scales immediately differentiates Euspondylus auyanensis from species of Anadia, which lack "a distinct band of much smaller scales along each side" (Oftedal, 1974: 206). Lateral scales in Anadia may be smaller than the dorsals, but the transverse rows continue unbroken (except near limb insertions) onto the sides of the body. With rare exception (A. escalerae described herein), species of Anadia differ from Euspondylus in having smooth rather than keeled dorsal scales. Species belonging to Anadia sensu stricto (at least including Oftedal's [1974] ocellata group) are elegantly slender and attenuate lizards (fig. 11); these are much different in habitus from any Euspondylus except for possibly the rare E. simonsii. ${ }^{8}$ The keeled dorsals as well as the zone of small lateral body scales immediately differentiates $E$. auyanensis from the heavier bodied species currently assigned to Anadia (e.g., A. blakei, figs. 12-13).

\footnotetext{
${ }^{7}$ However, of the few specimens of E. acutirostris used by Montero et al. (2002), one exchange specimen originally had been part of a series of four specimens at the Museo de Historia Natural La Salle (MHNLS). During his time on the staff there, Rivas re-identified the remaining three specimens as young Anadia marmorata, leaving one to wonder if the fourth specimen (formerly MHNLS 12678) had been also misidentified as $E$. acutirostris.

${ }^{8}$ D.M. Harris (personal commun.) informed us that the British Museum holotype of the Peruvian Euspondylus simonsii Boulenger "is at least as slender as Anadia petersi or A. rhombifera," which seems confirmed by a specimen of simonsii (AMNH R-104284) from $1560 \mathrm{~m}$ in Depto. Huánuco, Peru.
} 


\section{REMARKS}

Euspondylus auyanensis is known to have been collected on only two of the many expeditions to Auyantepui. The 1994 AMNHTERRAMAR Expedition failed to find it during a month's fieldwork in February and Stefan Gorzula found it only on one of his several trips to Auyantepui. Gorzula collected several specimens, all of which seem to have been lost. Myers and Donnelly (2008: 88-89) summarized the history:

Gorzula (1992: 276) discovered an unnamed species of Anadia on Auyantepui in 1984. According to Gorzula and Señaris (1999: 115-117) the species is known only from a single collection of seven specimens obtained "6 miles E Angel Falls" in May and June. The specimens were found mostly in concealment by day, in association with the frogs Stefania schuberti and Tepuihyla edelcae and the lizard Tropidurus bogerti. One "was observed basking on the edge of a vegetation mat ... [and on] being approached it dove into a small pool that was about $6 \mathrm{~cm}$ deep, and hid in the detritus on the bottom."

Gorzula and Señaris were unable to ascertain the present whereabouts of the specimens and therefore refrained from formally describing the species. They did, however, describe the individual lizard that was to have been designated holotype and indicated variation in the potential paratypes. The color in life "was dark olive with irregularly distributed black flecks ... ventral color of females was white with irregular black spots ... [male ventral color] similar to that of the females except ... tinged with red." Illustrations were unavailable.

Gorzula and Señaris (1999: 115-117) provided a detailed description of one lost specimen and notes on the others; measurements, however, had not been taken. The specimen described in detail had "loreal (frenocular?) large, contacting prefrontal and supralabials"; this was not indicated as a variable character and presumably applied to all specimens. The same condition, which we interpret as fusion of loreal + frenocular, also pertains to the holotype (fig. 2, upper right) and may be characteristic of the species. However, the scale anterior to the elongate subocular (fig. 2, upper right) might be interpreted as a reduced, posteriorly positioned frenocular. In any case, presence or absence of a frenocular is a variable character in some gymnophthalmids, as in Anadia blakei (q.v.).

Gorzula's locality lies in the northern part of the Auyán summit, whereas the type locality is at the southern edge. It would seem to be a fairly conspicuous lizard when it ventures out from cover, but hard to find if it seeks dry-season sanctuary in deep rock crevices. Euspondylus auyanensis is assumed to be endemic to the summit area.

\section{Anadia escalerae, new species}

Figures 8-9

Holotype: Museo de la Estación Biológica de Rancho Grande (EBRG) no. 1998, an adult female from La Escalera region, "132 km SE Río Cuyuní (= $46 \mathrm{~km}$ SE km 88) on road to Santa Elena, $1430 \mathrm{~m}$," Edo. Bolívar, Venezuela, collected by John E. Cadle, December 30, 1980.

ETYMOLOGY: The specific name, a latinized noun in the genitive case, is derived from $L a$ Escalera, a well-known regional name for the steep ascent up the slope of Sierra de Lema to the northern edge of the elevated Gran Sabana, on the road from El Dorado to Santa Elena de Uairén.

Diagnosis: Anadia escalerae most closely resembles $A$. pariaensis from the Península de Paria. The holotypes of pariaensis and escaler$a e$ are the only members of the genus known to have the prefrontals separated by an azygous scale (a variable character in pariaensis $^{9}$ and possibly in escalerae) and these specimens also have similar color patterns (cf. figs. 9, 10). A. escalerae differs from $A$. pariaensis in having weakly keeled (vs. smooth) dorsal scales, in having a subocular scale protruded downward between 4th and 5 th supralabials, and in differing configurations of various head scales (see comparisons).

\footnotetext{
${ }^{9}$ Based on an unreported specimen from Península de Paria in the Museo de Biología de la Universidad del Zulia, Maracaibo (MBLUZ 930). This additional specimen of $A$. pariaensis, a male, has been at least temporarily lost in transit while on loan (Rivas, unpublished data).
} 

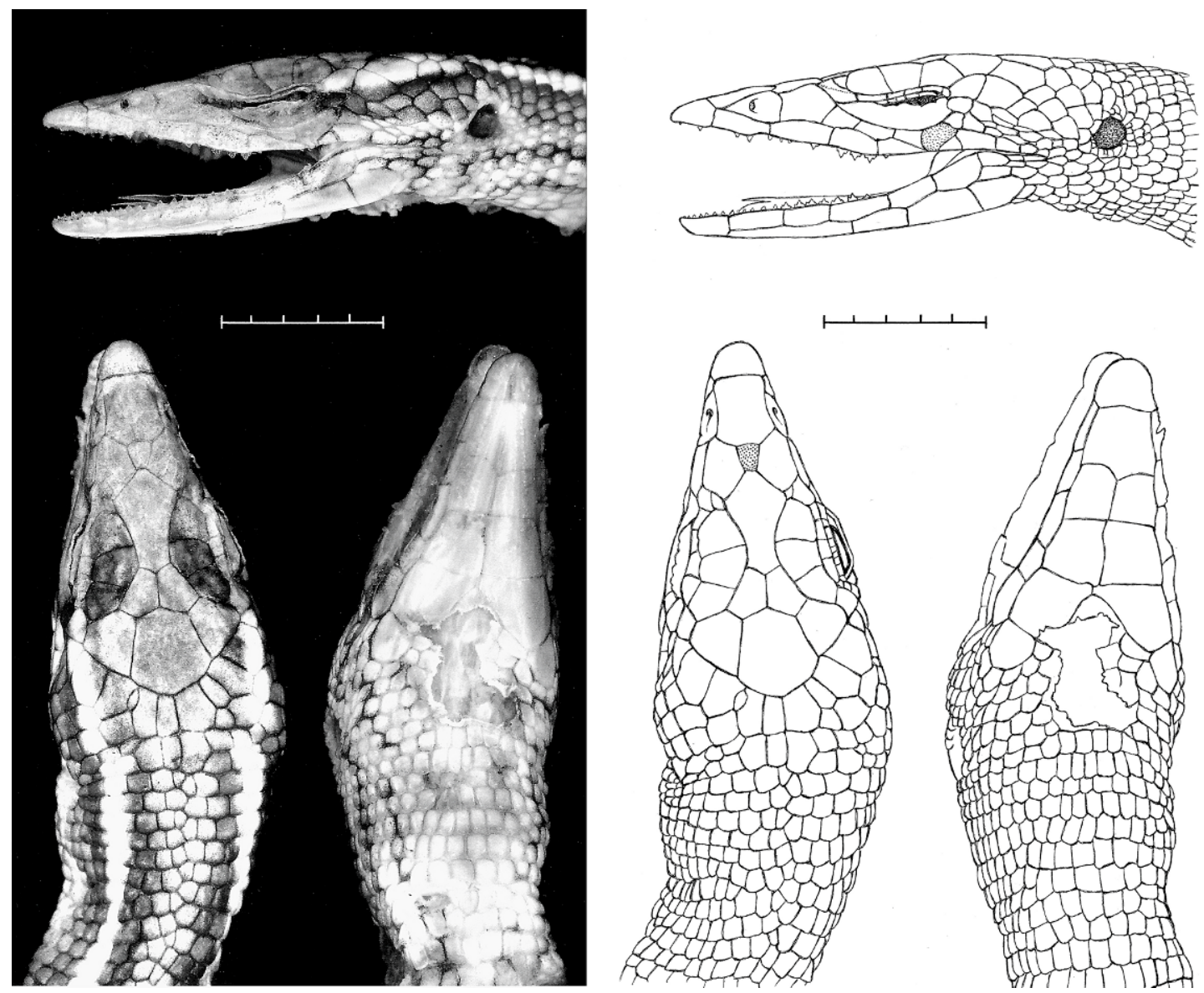

Fig. 8. Anadia escalerae, new species. Lateral, dorsal, and ventral views of head of holotype (EBRG 1998). Unusual scales (gray tone in drawings) include fourth sublabial in contact with lip and azygous scale between paired prefrontals. Scalation of lower eyelid not shown in drawing because of desiccation and distortion; white areas in ventral view reflect insect damage. Scale lines $=5 \mathrm{~mm}$.

\section{DESCRIPTION OF HolOTYPE}

It is a sexually mature female with convoluted oviducts. About $166 \mathrm{~mm}$ total length, $63 \mathrm{~mm}$ SVL (table 2). Found dead according to its field tag and damaged apparently by insects, especially on right side of head and on throat; left arm lacking except for humeral bone.

Habitus AND Proportions: A slender, long-tailed lizard with relatively small limbs; snout attenuate, flat in profile. Head length $20 \%$ of SVL, 1.8 times longer than wide, 1.6 times wider than high; head wider than neck. Neck long, $67 \%$ of head length, $25 \%$ of trunk length. Snout-axilla length $67 \%$ of trunk length, $37 \%$ of SVL. Body wider than deep. Tail dorsoventrally flattened (somewhat flat above and below in profile), about 1.6 times longer than SVL. Limbs pentadactyl, all digits clawed (lacking left forelimb). Forelimb $22 \%$ of SVL, $41 \%$ of trunk length; hind leg $33 \%$ of SVL, $62 \%$ of trunk length; based on measurements of arm and leg (table 2, note b), longest digits of appressed limbs would barely overlap.

Tongue And Dentition: Tongue lanceolate, largely unpigmented, distally becoming gray close to fork (tips unpigmented). Upper surface behind fork covered with imbricate scalelike papillae, except that proximal bifurcation of tongue has transverse plicae. Scalelike papillae extend onto ventrolateral sides of tongue. Raised medioventral side of 


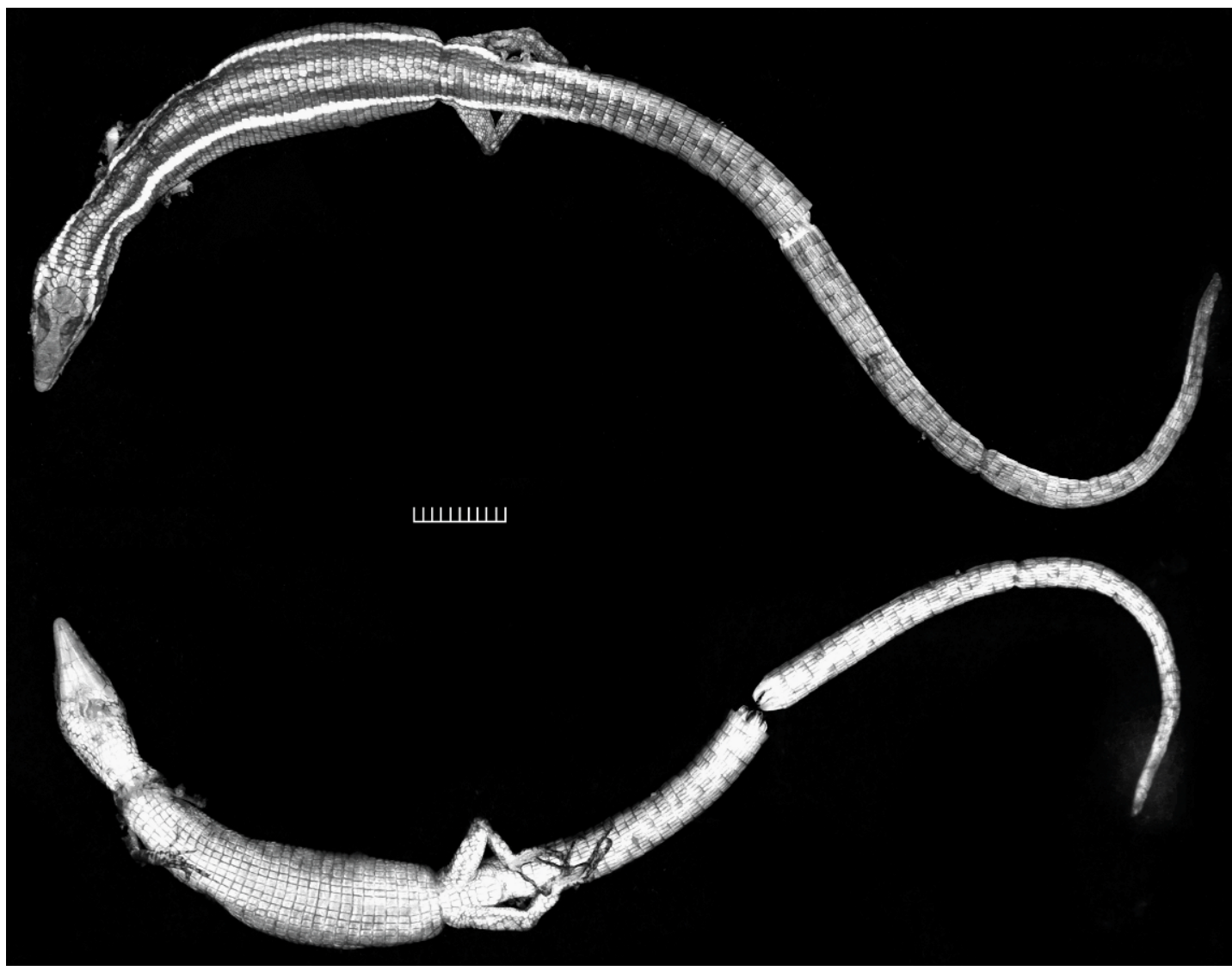

Fig. 9. Anadia escalerae, new species. Dorsal and ventral views of female holotype (EBRG 1998), showing habitus and color pattern in preservative. Scale line $=10 \mathrm{~mm}$.

tongue with numerous pairs $(>10)$ of thin, oblique, anteriorly converging and pointed (chevronlike) infralingual plicae; anterior pair of infralingual plicae swollen, bluntly pointed, and much larger than those following. No obvious medioventral grove (but tongue slightly desiccated).

Anterior maxillary and dentary teeth conical, virtually without recurvature, becoming larger and weakly tricuspid posteriorly.

Scutellation: Dorsum of head (fig. 8) with normal complement of Anadia head plates (cf. Oftedal, 1974: fig. 1) except for presence of well-developed azygous scale separating paired prefrontals.

Rostral plate much wider than deep, separated from nasal, laterally in contact with first supralabial, dorsally in contact with large frontonasal. Frontonasal with nearly straight anterior edge and medially concave on posterior edge. Paired prefrontals separated by azygous plate in contact with frontonasal anteriorly and with frontal posteriorly. Frontal hexagonal, with blunt anterior point and obtuse posterior one, widest anteriorly, concave posterolaterally. Paired frontoparietals with long medial suture, in contact with interparietal, parietals, and two posterior supraoculars. Three large supraoculars; a small presupraocular situated between prefrontal and first supraocular. Interparietal slightly longer than wide, rounded posteriorly. Parietals not as wide as interparietal and not extending as far posteriad. A series of eight medium-sized occipitals (postparietals) circling common posterior margin of parietals and interparietal. Three median postoccipitals larger than other dorsal neck scales. 


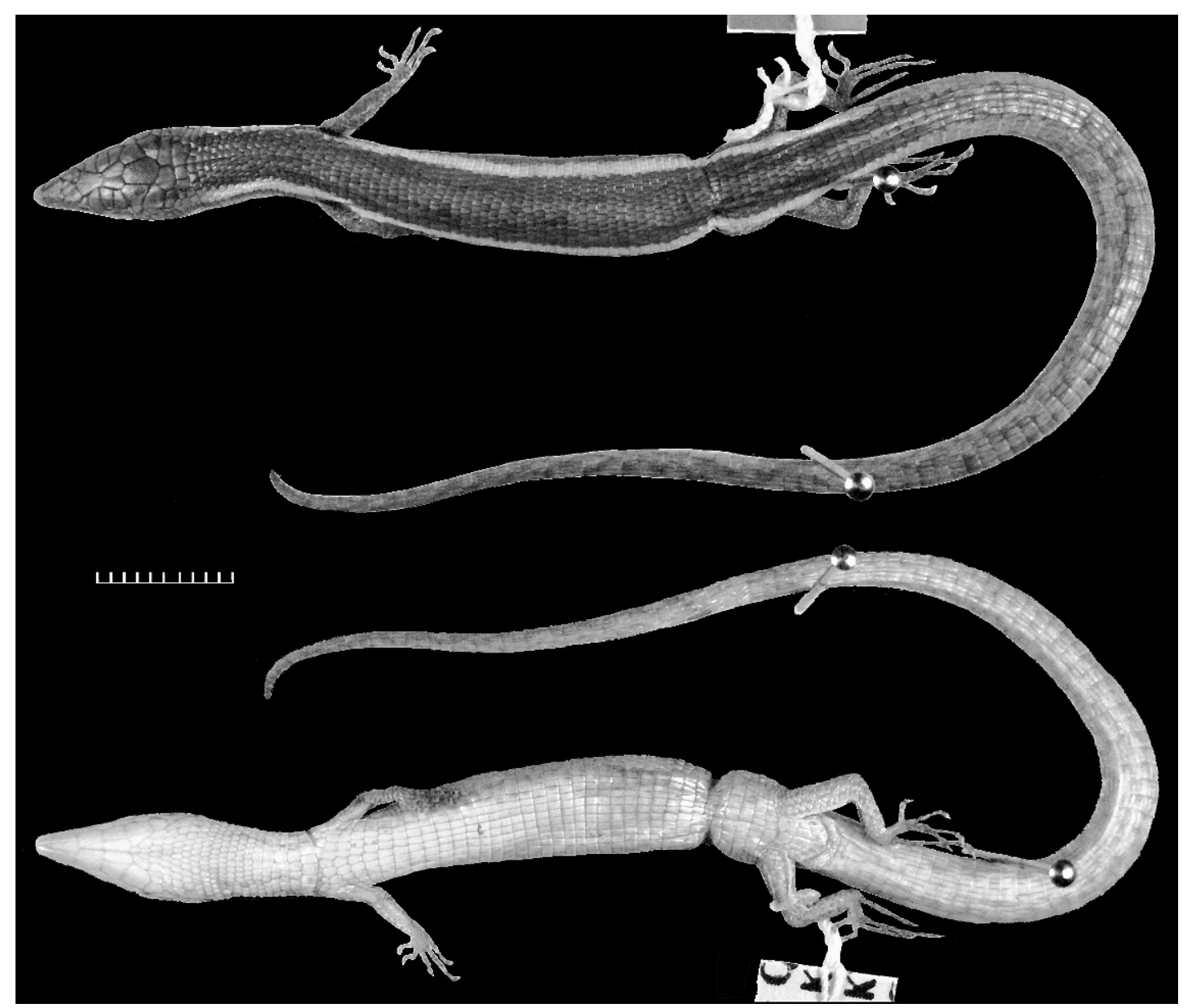

Fig. 10. Anadia pariaensis Rivas, La Marca, and Oliveros. Dorsal and ventral views of male holotype (EBRG 2742). Scale line $=10 \mathrm{~mm}$. (Photographs courtesy of Francisco Bisbal and Javier Sánchez).

Nasal scale entire, nostril situated slightly anterior of center. Nasal scale separated from rostral by anterior corner of frontonasal, posteriorly in broad contact with loreal. Loreal large, in broad contact with first superciliary and frenocular. At least one small preocular and a larger postocular. First superciliary (or "presuperciliary") large, followed by four shorter superciliaries. No small azygous scales between superciliaries and supraoculars. Frenocular followed posteriorly by five suboculars. Fourth subocular extending to lip between supralabials 4-5 (evident on both sides of head). Eight supralabials (including a small scale above corner of mouth).

Orbital areas desiccated and damaged. About six ciliaries along upper eyelid. Lower eyelid scales translucent, right side (not illustrated) with a palpebral disk or median window of four higher-than-wide rectangular panes.

Temporal scales subimbricate, smooth, with flat surfaces, larger above, smaller below. Ear opening a broad (nearly circular) ovoid, slightly inclined posterodorsally, edged with small, slightly pebblelike scales; tympanum recessed, mostly unpigmented.

Underside of head with five infralabials on each side (not counting a few small scales at corner of mouth). A large mental followed by large postmental in lateral contact with first two infralabials. Three pairs of large genials in lateral contact with infralabials 2-5; first two pairs of genials in broad median contact, third 
pair in narrow median contact. One large postgenial on each side, in contact with last genial and infralabial 5. Anterior gular region damaged. Posteriorly, small to medium-size gular scales with slightly rounded surfaces, subimbricate. Gulars arranged in transverse rows, becoming slightly larger posteriad, culminating in poorly defined collar row of subequal scales. Side of neck between ear and collar pebbled with subequal, rounded juxtaposed scales.

Middorsal scales 63 (table 2, note c). Dorsal scales on neck subimbricate, somewhat irregularly shaped, with rounded surfaces. Dorsal body scales mainly quadrangular, some irregularly shaped but most are longer than wide or occasionally square, in transverse rows only. Most dorsals weakly keeled-keels thick but not sharply defined and not extending length of scale, occasionally confined tuberclelike to middle of scale. Lateral scales (below dorsolateral pale stripes) smooth, otherwise similar to dorsals but smaller and more variable in shape.

Ventral scales much wider than dorsals, smooth, juxtaposed, quadrangular, longer than wide except for two median longitudinal rows of square scales on belly; in 12 longitudinal rows at midbody (including small rectangular ventrolateral plates) and 34 transverse rows between collar and preanal scales.

Four anterior rows of paired preanal scales. Eight marginal preanal scales anterior to vent, the middle four larger than the lateral ones. Femoral pores poorly developed, in nonswollen pore scales mostly in linear contact; about 5 pores on left thigh and 10 on right. Pores do not extend onto preanal area.

Caudal scales disposed in transverse rows of uniformly rectangular scales all around tail. Caudal scales subimbricate, smooth except that some dorsals are weakly keeled on base of tail.

Forearms damaged. Dorsal surfaces of lower arm with large, smooth subimbricate scales; ventral side of lower arm with smaller scales. Hind limbs with large, smooth subimbricate to imbricate scales on anterior face of thigh; scales similar but smaller on ventral side of thigh. Dorsal and posterior sides of thighs, and dorsal surface of lower leg, pebbled with small, round and raised juxtaposed scales.
Ventral side of lower leg with large smooth imbricate scales.

Moderate-size scales atop hands and feet. Supradigital scales single; upper and lower ungual-sheath scales covering base of claws, leaving tips well exposed. Palms and soles with small, slightly raised juxtaposed scales. No enlarged thenar scale at base of pollex. Subdigital lamellae mostly single. Longest (4th) finger with 14 subdigital lamellae, longest (4th) toe with 17 subdigital lamellae.

Coloration: In preservative (fig. 9), a conspicuous white dorsolateral stripe on each side, from eye to base of tail, set on ground color of rich dark brown. Middorsum pale brown, with an ill-defined dark brown vertebral streak. Head grayish brown, turning paler yellowish brown on snout and chin. An illdefined pale blue stripe extending from corner of mouth through ear to arm insertion, this marking edged below by a brown line; lower side of neck pale blue with vestige of another brown line parallel to the one above it. Chest, belly, and lower sides light brownish gray, becoming whitish with faint pale brown mottling underneath hind legs and tail.

\section{COMPARISONS}

Anadia escalerae (fig. 9) resembles some specimens of $A$. steyeri and the holotype of A. pariaensis (fig. 10) in general color pattern. It especially resembles the holotype of $A$. pariaensis in possession of an azygous scale inserted between the paired prefrontals (cf. fig. 8 with Rivas et al., 1999: fig. 2). Nature of the median contact between prefrontals is used as a diagnostic character in Anadia, but separation by an azygous scale seems previously unreported. There are a number of differences separating the two specimens, including the following:

1. A. escalerae has weakly keeled dorsal scales, which distinguishes it from $A$. pariaensis and other congeners.

2. A. escalerae has a subocular scale prominently protruded downward to the lip, separating the 4th and 5th supralabials. The subocular above labials 4-5 lacks downward angularity in A. pariaensis (and the related $A$. steyeri). 
TABLE 2

Measurements (in mm) and Scale Counts of Holotype of Anadia escalerae, New Species

\begin{tabular}{|c|c|}
\hline Specimen & EBRG 1998 ad. 우 \\
\hline Snout-vent length (SVL) & 63 \\
\hline Tail length & $102+(-$ tip $)$ \\
\hline Head length (oblique, snout-ear) & 12.7 \\
\hline Greatest head width & 7.2 \\
\hline Greatest head depth & 4.5 \\
\hline Snout-axilla length & 23 \\
\hline Neck length ${ }^{\mathrm{a}}$ & 8.5 \\
\hline Trunk (axilla to groin) & 34 \\
\hline Forelimb length $^{\mathrm{b}}$ & 14 \\
\hline Hind limb length ${ }^{\mathrm{b}}$ & 21 \\
\hline Subdigital lamellae finger IV & 14 \\
\hline Subdigital lamellae toe IV & 17 \\
\hline Middorsal scales ${ }^{\mathrm{c}}$ & 63 \\
\hline Ventrals, longitudinal rows ${ }^{\mathrm{d}}$ & 12 \\
\hline Ventrals, transverse rows ${ }^{\mathrm{e}}$ & 34 \\
\hline Scales around midbody ${ }^{\mathrm{f}}$ & 40 \\
\hline Supralabials & 7 \\
\hline Infralabials & 5 \\
\hline
\end{tabular}

${ }^{\mathrm{a}}$ Length of neck from posterior edge of ear to forearm held at right angle to body.

${ }^{b}$ Limb length measured from axilla or groin to tip of claw of longest digit. (Owing to stiffness, the right forelimb length $=$ sum of separate measurements of upper and lower limb.)

${ }^{\mathrm{c}}$ Middorsal scales counted from postoccipitals to level of posterior edge of thigh held at right angle to body.

${ }^{\mathrm{d}}$ Longitudinal ventral rows counted at midbody (transverse ventral row 17) and including small ventrolateral rectangular plates.

${ }^{\mathrm{e}}$ Transverse rows of ventrals counted between collar and preanals.

${ }^{\mathrm{f}} \mathrm{S}$ cales around midbody counted at level of transverse ventral row 17.

3. A. escalerae has a well-defined row of about eight relatively small and mediumsized occipitals (postparietals) circling the common posterior margins of the interparietal and parietal plates. In contrast, $A$. pariaensis and $A$. steyeri have the interparietal and parietals in angular contact with four large postoccipitals in a less welldefined row (compare fig. 8 with Rivas et al., 1999: fig. 2 and Oftedal, 1974: fig. 14).

4. A. pariaensis and A. steyeri have a relatively wide frontal plate, which is laterally concave and narrow in $A$. escalerae (fig. 8).

5. The nasal scale fails to reach the rostral in A. escalerae (fig. 8), whereas it is in contact with the rostral in $A$. pariaensis and $A$. steyeri.

6. Members of the third pair of genials are in narrow medial contact in $A$. escalerae (fig. 8), but are separated by a broad wedge of pregulars ( 3 scales across) in the A. pariaensis type.

Even without being able to assess extent of variation in any one character, these differences in total lead to the inescapable conclusion that the Anadia of $\mathrm{La}$ Escalera is specifically distinct from populations north of the Río Orinoco. This new lizard is a slender, attenuate species that seems to belong with Anadia sensu stricto as defined by the generic type (fig. 11). Despite the differences discussed above, $A$. escalerae may be most closely related to $A$. pariaensis from the Península de Paria-roughly $500 \mathrm{~km}$ NNW of La Escalera; the holotypes are of similar appearance (figs. 9, 10) and, even though it may prove to be a variable character, both share the highly unusual condition of an azygous scale separating the prefrontals. ${ }^{10}$

The slender habitus, weakly keeled scales, and coloration of Anadia escalerae readily distinguish it from its geographically nearest neighbor on the Chimantá massif (roughly $100 \mathrm{~km} \mathrm{SW}$ of La Escalera). The unnamed Chimantá species is a much more robust lizard with a nearly uniform beige coloration (color photos in Gorzula, 1992: 310, under the nomen nudum "A. breweri"; also Gorzula and Señaris, 1999: 114-115, photo 88).

\section{REMARKS}

The type locality is on La Escalera-the steep ascent up the slope of Sierra de Lema to the northern edge of the elevated Gran Sabana (Bolívar State, on road from El Dorado to Santa Elena de Uairén). For maps and a description and photographs of the area, see Duellman (1997: 4-8); Gorzula and Señaris

\footnotetext{
${ }^{10}$ An azygous scale separating the prefrontals seems to be absent or at least very rare among all other Cercosaurini. The type specimen of Cercosaura argulus has the prefrontals separated by an anterior extension of the frontal (Peters, "1862" [1863]: 184, pl. 1, fig. 3a; also Uzzell, 1973: 37). This appears to be an anomaly unrelated to the azygous scale in Anadia.
} 

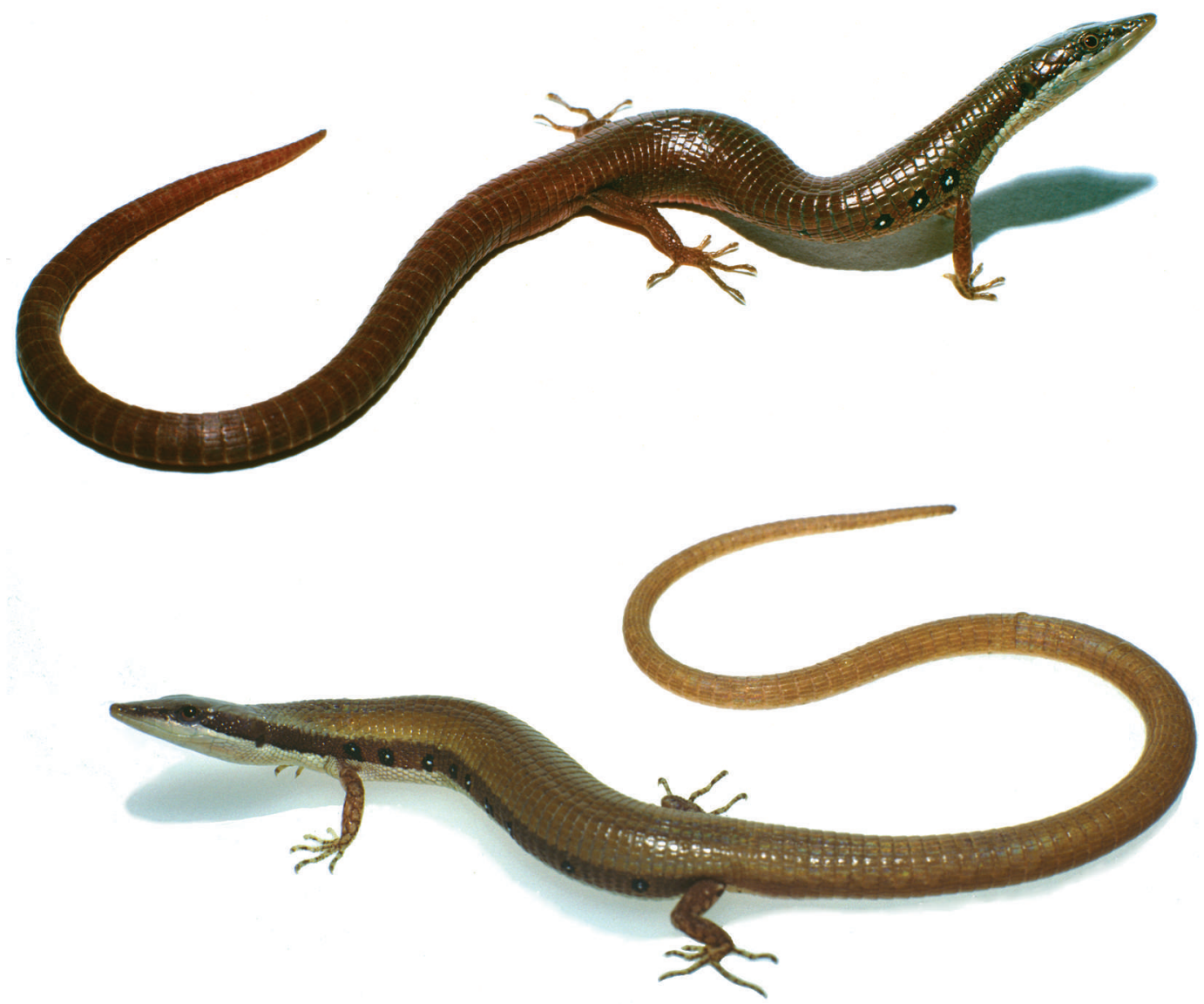

Fig. 11. Two microteiids showing typical habitus of the genus Anadia sensu stricto. Upper: A. ocellata Gray-the generic type species. An adult male from western Panama (AMNH R-114306, upper Río Chiriquí, Chiriquí, $1000 \mathrm{~m}$ ). Lower: A. vittata Boulenger. An adult male from northwestern Colombia (AMNH R-124007, Puerto Mutis, Bahia Solano, Chocó). (From transparencies by C. W. Myers).

(1999: 249-250) provided brief notes on roadside localities.

The holotype was found dead by John Cadle, at an approximate elevation of $1430 \mathrm{~m}$, at a campsite $3.8 \mathrm{~km}$ by road from the top of the Escalera (Cadle, personal commun.). According to Duellman (1997: 5), the elevation is " $1270 \mathrm{~m}$ at the crest of the road [which then] drops only about $50 \mathrm{~m}$ to the nearly flat Gran Sabana;" Gorzula and Señaris (1999: 250, locality U-055) gave a higher elevation of $1340 \mathrm{~m}$ on the road "at beginning of altiplancie, topography relatively flat." The elevations recorded by Cadle and Duellman, and probably by Gorzula, were obtained with handheld altimeters; unless adjustment is made for daily atmospheric changes, altimeter errors exceeding $\pm 100 \mathrm{~m}$ are commonplace in highland areas.

Cadle (personal commun.) described the type locality as a fine forest with a very high canopy and with epiphytes covering everything. Orchids seemed scarce, but ferns, bromeliads, and lianas were abundant. There was heavy leaf litter and many rotten logs.

Several additional specimens of this species were collected on La Escalera by Alfredo Paolillo and cataloged in the Museo de la Estación Biológica de Rancho Grande, but those specimens seemingly were lost while on loan (F.J. Bisbal, personal commun.). 
Anadia blakei Schmidt, 1932

Figures 12-14

Anadia blakei Schmidt, 1932: 161-162 (holotype FMNH 17795, an adult female from "camp at altitude of 5,000 feet [1524 m] on Mount Turumiquire, [= Cerro Turimiquire, Estado Sucre], Venezuela. Collected March 10, 1932 by E. R. Blake"). Oftedal, 1974: 250 252 (generic revision). Peters and Donoso-Barros, 1970: 40).

Anadia marmorata: Rivas and Oliveros, 1997: 69 (their specimen, EBRG 2746, is described below).

\section{Description of New Specimen}

The specimen (EBRG 2746) is an adult male from Cerro Humo $900 \mathrm{~m}$ elevation, Parque Nacional Península de Paria, Estado Sucre. Collected August 22, 1992 by Ramón Rivero (field no. RAR-1093).

Habitus And Proportions: Compared with most other species of Anadia (e.g., figs. 9-11), Anadia blakei is a relatively heavy-bodied lizard. The new specimen (fig. 12) is an adult male $91 \mathrm{~mm} \mathrm{SVL} \mathrm{+}$ $157 \mathrm{~mm}$ tail $=248 \mathrm{~mm}$ total length. The snout is attenuate and dorsally flattened, appearing nearly flat in profile. Head length $26 \%$ of SVL, 1.5 times longer than wide, 1.3 times wider than high; head swollen across temporal region (probably a secondary sex character) and distinctly wider than neck. Neck $51 \%$ of head length, $27 \%$ of trunk length. Snout-axilla length $89 \%$ of trunk length, $43 \%$ of SVL. Body wider than deep. Tail rounded. Limbs pentadactyl, all digits clawed; finger III nearly as long as finger IV, toe IV distinctly longer than toe III. Forelimb $29 \%$ of SVL, 58\% of trunk length; hind leg $34 \%$ of SVL, $69 \%$ of trunk length; longest digits of appressed limbs overlap. Measurements are given in table 3.

Tongue and Dentition: Tongue lanceolate, pale gray anteriorly. Upper surface of tongue behind fork covered with imbricate scalelike papillae (proximal part of tongue not examined). Anteriorly converging (chevronlike) infralingual plicae present.

Anterior maxillary and dentary teeth nearly conical in profile, becoming weakly bicuspid posteriorly (with a very small cusp on anterior face of tooth). Teeth with a slight curvature mediad and tending to be largest posteriorly, but without definite gradation in size. Large and small teeth in close proximity even anteriorly.

Scutellation: Dorsum of head with normal complement of Anadia head plates (Oftedal, 1974: fig. 1) except that frenocular is lacking in this specimen (fused with loreal). Rostral plate much wider than deep, in broad contact with nasal, laterally in contact with first supralabial, dorsally in contact with large frontonasal. Frontonasal pentagonal, with slightly convex anterior edge and pointed posterior edge. Paired prefrontals in relatively broad contact. Frontal hexagonal, widest anteriorly. Paired frontoparietals with long medial suture. Three supraoculars, anterior one largest; a tiny presupraocular on left side adjacent to first superciliary, between prefrontal and first supraocular. Interparietal hexagonal, much longer than wide. Parietals much wider than interparietal but not extending as far posteriad. Four large occipitals (postparietals) behind interparietal and parietals. Four median postoccipitals behind median pair of occipitals, larger than other dorsal neck scales.

Nasal scale entire, nostril situated in center. Nasal scale anteriorly narrowed, in broad contact with rostral anteriorly and loreal posteriorly. Loreal large, in broad contact with first superciliary and supralabials 2-3. Frenocular absent, apparently fused with loreal. One anteriorly pointed preocular and two small postoculars. First superciliary (or "presuperciliary") large, followed by five shorter superciliaries. No small azygous scales between superciliaries and supraoculars. Suboculars small and narrow, not forming a continuous series under eye. Eight supralabials, first seven large, the eighth small.

Upper eyelids with $10 / 8$ ciliaries, lower eyelids with 11/12. Palpebral disk lightly pigmented, its moderately large scales not forming a median window of regular-sized panes.

Temporal scales relatively small and subequal, juxtaposed, smooth, with raised rounded surfaces. Ear opening a vertical ovoid, edged with small pebblelike scales; tympanum recessed, transparent.

Underside of head with eight infralabials on each side (last two small). Large mental followed by larger postmental in lateral contact with first two infralabials. Three 


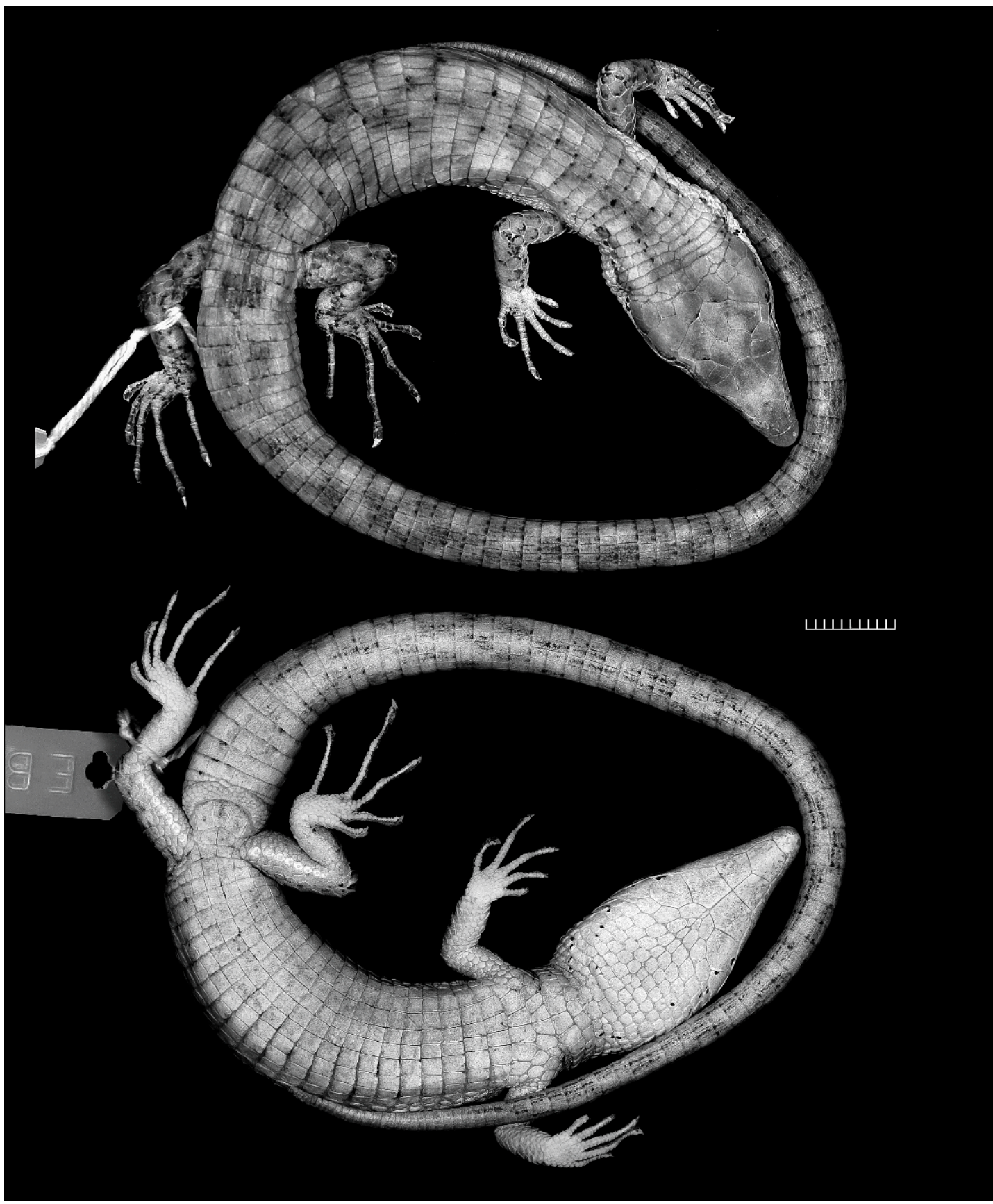

Fig. 12. Anadia blakei Schmidt. Dorsal and ventral views of male specimen (EBRG 2746) from Cerro Humo, Peninsula de Paria, Estado Sucre. Scale line $=10 \mathrm{~mm}$.

pairs of large genials in lateral contact with infralabials $2-5$; first two pairs of genials in broad median contact, third pair broadly separated by median wedge of gular scales.
One large postgenial on each side, in contact with last genial and in point contact with infralabial 5. Gular scales of moderate size, flat surfaced, juxtaposed. Gulars arranged in 


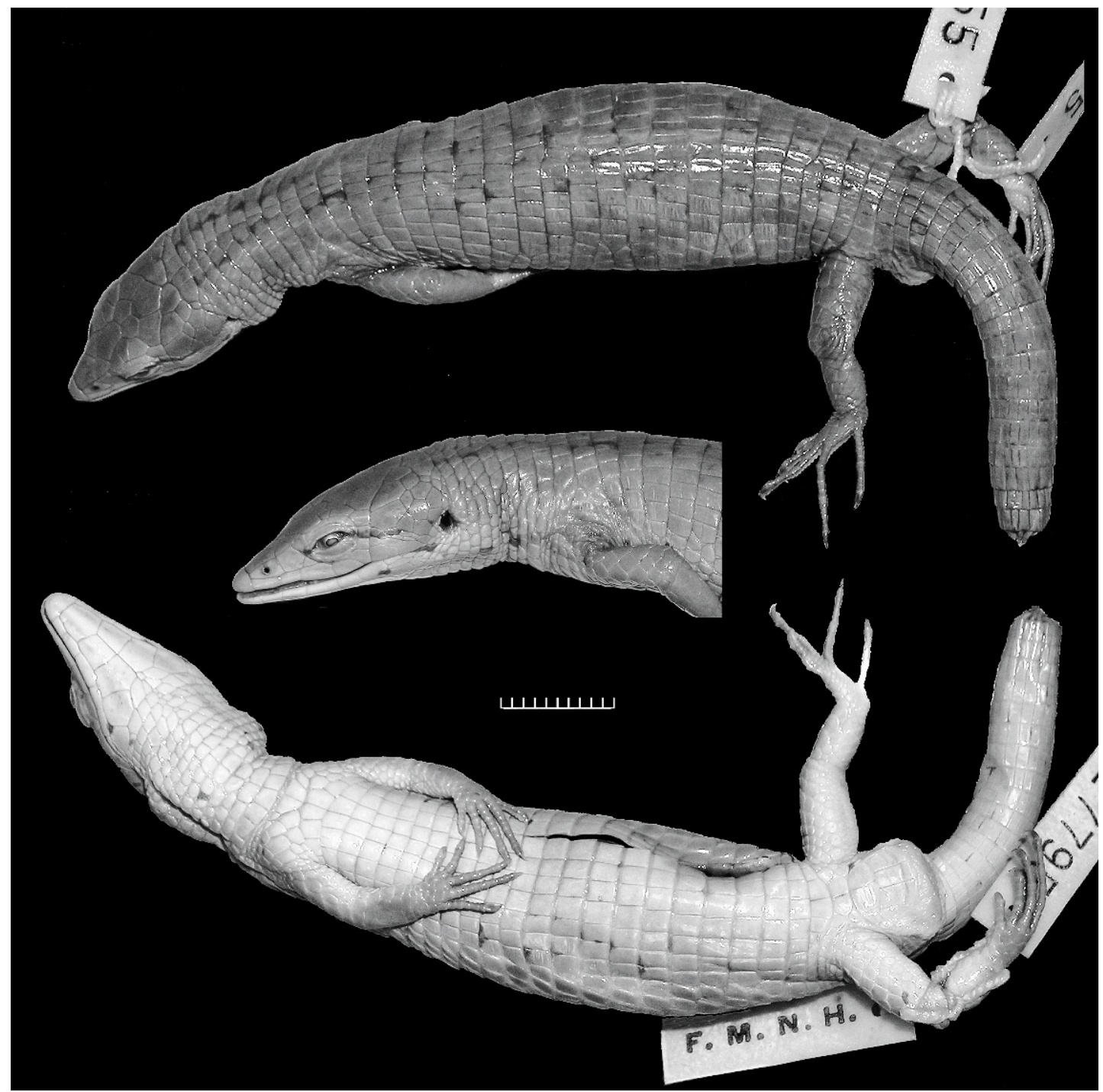

Fig. 13. Anadia blakei Schmidt. Views of the female holotype (FMNH 17795), showing habitus and color pattern in preservative. Scale line $=10 \mathrm{~mm}$. (Photographs courtesy of Alan Resetar, Field Museum of Natural History).

transverse rows of subequal scales, culminating in three well-defined collar rows of larger scales. Side of neck between ear and collar pebbled with subequal, rounded juxtaposed scales.

Middorsal scales 30 (table 3: note c). Dorsal scales smooth, subimbricate to imbricate, with flat surfaces. Dorsal body scales rectangular (a few irregularly shaped), longer than wide, in transverse rows only. Lateral scales similar to dorsals but smaller and somewhat variable in shape.

Ventral scales nearly square, shorter than rectangular dorsals, smooth, subimbricate, arranged in both transverse and longitudinal rows. About nine longitudinal rows of ventrals at midbody (but ventrals merge in size and shape with lateral scales, so that any count is subjective) and 23 transverse rows between collar and preanal scales. 

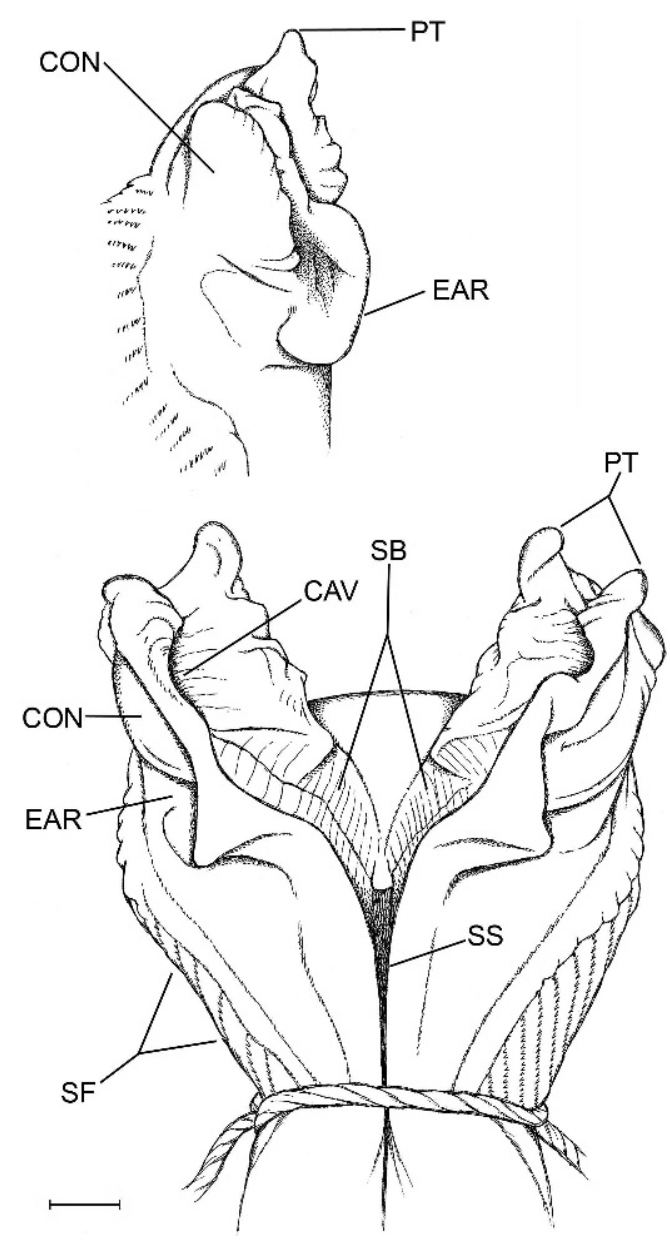

Fig. 14. Hemipenis of Anadia blakei Schmidt. Manually everted right organ of EBRG 2746, showing distal part of sulcate side; inset at top shows lateral view of left lobe. On the asulcate side of the hemipenis (not shown), the spinulate branches of the chevrons extend transversely across the organ as medioproximal flounces below a large nude area. (The more basal section of this hemipenis was not recovered; see text.) Abbreviations: CAV, concavity holding terminus of sulcus-spermaticus branch; CON, convexity behind the concavity; EAR, earlike structure proximal to the convexity; PT, papillate tips at apices of each lobe; SB, branch of sulcus spermaticus; SF, spinulate flounces; SS, sulcus spermaticus. Scale line $=1 \mathrm{~mm}$.

Two anterior rows of paired preanal scales. Five marginal preanal scales anterior to vent, the three middle ones larger than the lateral ones. Femoral pores weakly developed, slight-
TABLE 3

Measurements (in mm) and Scale Counts of New Specimen of Anadia blakei Schmidt, 1932

\begin{tabular}{|c|c|}
\hline Specimen & EBRG 2746 ad. $\delta$ \\
\hline Snout-vent length (SVL) & 91 \\
\hline Tail length & 157 \\
\hline Head length (oblique, snout-ear) & 24 \\
\hline Greatest head width & 16 \\
\hline Greatest head depth & 12 \\
\hline Snout-axilla length & 40 \\
\hline Neck length ${ }^{\mathrm{a}}$ & 12.3 \\
\hline Trunk (axilla to groin) & 45 \\
\hline Forelimb length ${ }^{\mathrm{b}}$ & 26 \\
\hline Hind limb length ${ }^{\mathrm{b}}$ & 31 \\
\hline Subdigital lamellae finger IV & 15 \\
\hline Subdigital lamellae toe IV & 20 \\
\hline Middorsal scales ${ }^{c}$ & 30 \\
\hline Ventrals, longitudinal rows ${ }^{\mathrm{d}}$ & 9 \\
\hline Ventrals, transverse rows ${ }^{\mathrm{e}}$ & 23 \\
\hline Scales around midbody ${ }^{\mathrm{f}}$ & 28 \\
\hline Supralabials & 8 \\
\hline Infralabials & 8 \\
\hline
\end{tabular}

${ }^{\mathrm{a}}$ Length of neck from posterior edge of ear to forearm held at right angle to body.

${ }^{\mathrm{b}}$ Limb length measured from axilla or groin to tip of claw of longest digit. (Owing to stiffness, the right forelimb length $=$ sum of separate measurements of upper and lower limb.)

${ }^{\mathrm{c}}$ Middorsal scales counted from postoccipitals to level of posterior edge of thigh held at right angle to body.

${ }^{\mathrm{d}}$ Longitudinal ventral rows counted at midbody (at transverse ventral row 12). Count is approximate because of size gradation between ventral and ventrolateral scales.

${ }^{\mathrm{e}}$ Transverse rows of ventrals counted between collar and first row (of 3) of preanals.

${ }^{\mathrm{f}}$ Scales around midbody counted at level of transverse ventral row 12.

ly swollen pore scales in linear contact; eight pores on each thigh (including a barely discernible distal pore on left). Pores do not extend onto preanal area.

Caudal scales arranged in rows of regular width around tail, the scales disposed in transverse rows of uniformly rectangular scales on dorsal and lateral surfaces and in both transverse and longitudinal rows of larger rectangular scales ventrally. Caudal scales subimbricate, smooth.

Dorsal surfaces of upper and lower arms with large, smooth subimbricate scales; ventral sides with smaller juxtaposed scales. Hind limbs with large, smooth subimbricate to 
imbricate scales dorsally, the scales becoming much smaller on posterior face of thigh. Ventral side of lower leg with large, smooth, imbricate scales.

Moderate-size scales atop hands and feet. Supradigital scales single; upper and lower ungual-sheath scales covering base of claws, leaving tips well exposed. Palms and soles with small, slightly raised juxtaposed scales. No enlarged thenar scale at base of pollex. Subdigital lamellae on fingers mostly single, with a few basal ones doubled; subdigital lamellae on toes double on basal halves, single distally. Longest (4th) finger with 15 subdigital lamellae, longest (4th) toe with 20 subdigital lamellae.

Coloration: In preservative (fig. 12) brown with grayish suffusions and indefinite black markings. See Comparisons below.

Hemipenis: The right retracted hemipenis of EBRG 2746 was removed for manual eversion and study especially of apical configuration; owing to misjudgment while attempting to minimize destructive dissection, the base of the tail was insufficiently opened and the organ was transversely incised an unknown distance above the base. Manual eversion was more difficult than expected owing to the stiffness of the spinulate flounces. The organ consequently was softened in a 3\% solution of $\mathrm{KOH}$ for a total of 29.5 hours, in four sessions spaced over several days; it was stored in diluted glycerin between $\mathrm{KOH}$ immersions (Myers and Cadle, 2003: 300). The following description excludes the unrecovered basal part of the organ.

The hemipenis is distinctly bilobed with papillate tips (fig. 14). The broad medial parts of both the sulcate and distal part of the asulcate sides of the organ are nude; the nude area on the asulcate side extends into the crotch. Laterally on each side is a close-set series of proximally pointed chevron-shaped flounces bearing comblike rows of minute spinules; the branches of the chevrons are unequal, those on the asulcate side shorter. Proximally, the branches of the chevrons extend transversely across the asulcate side below the large asulcate nude area (not figured, but see "medioproximal asulcate flounces" defined under Notes on Hemipenial Variation in the Gymnophthalmidae).
The sulcus spermaticus runs a medial course and bifurcates centripetally as it enters the lobular crotch; each branch then extends distally between raised walls of stiff tissue, to terminate near the end of the lobe in a concavity below a pair of large flat apical papillae. The floor of a sulcus branch is broad, especially proximally, and transversely ridged for its entire course.

In lateral view of a lobe (fig. 14, inset), the raised tissue wall that flanks the sulcus branch is convex above, which reflects the oppositeside concavity that receives the end of the branch. Proximal to this lateral convexity, the side of the raised tissue wall is concave and curved in an earlike shape. The short, distal chevrons flank the base of the lobe, but the asulcate side of the lobe is nude, continuous with the bare crotch and distal part of the asulcate side.

\section{COMPARISONS}

The male specimen from Cerro Humo compares favorably with photographs of the female holotype ${ }^{11}$ from Cerro Turimiquire, except in having a noticeably wider head (cf. figs. 12, 13), which reflects male sexual dimorphism (Oftedal, 1974: 250). The new specimen lacks a frenocular, agreeing with a published figure of the right side of the holotype (Oftedal, 1974: fig. 20B); but a triangular frenocular is present on the left side of the holotype (fig. 13).

Both specimens are brown with some inconspicuous black flecking. The holotype (fig. 13) has a weak, black postocular line extending toward the ear and the hint of a pair of parallel black lines atop the neck. In the Cerro Humo specimen the black postocular line extends brokenly through the top of the ear, thence rising slightly to connect with one of the parallel lines atop the neck; additionally there is a punctuated black line extending from the mouth and across the lower edge of the ear onto the neck, giving the appearance of a black-edged pale postocular stripe ending on

\footnotetext{
${ }^{11}$ Oftedal (1974: table 13) cited this specimen as male. However, Schmidt's (1932: 161) original designation as "adult female" is supported by its relatively narrow head and nonswollen tail base (fig. 13), as compared with an adult male (fig. 12) of identical size (91 mm SVL).
} 
the shoulder. The Cerro Humo specimen is indefinitely suffused with gray above; the underside of the head is whitish, becoming very pale brown over the venter and light brown with grayish suffusions underneath the tail.

Robust species such as Anadia blakei and $A$. marmorata are markedly different in habitus from the slightly built, attenuate lizards usually thought of as Anadia (compare figs. 9-11 with figs. 12-13). The monophyly of the genus remains to be established.

\section{REMARKS}

The new specimen of Anadia blakei was found by Ramón Rivero on a palm tree at $900 \mathrm{~m}$ on Cerro Humo. It extends the known range approximately $160 \mathrm{~km}$ eastward from the type locality at about $1500 \mathrm{~m}$ on Cerro Turimiquire. The species has also been reported from Cerro Negro, Caripe, roughly $60 \mathrm{~km}$ E of Cerro Turimiquire in Estado Monagas (Oftedal, 1974).

Because of continuing research carried out on the Turimiquire massif and Península de Paria, it is apparent that this region has high diversity and endemism. Even though the region is still poorly known, it appears to be an area of biogeographic importance. The Turimiquire massif and the Península de Paria contain endemic elements, as well as an array of faunal and floral elements that seem to be associated with those of the central coastal range to the west, the islands of Trinidad and Tobago to the east, and the Guayana Shield and Amazonia to the south (Steyermark, 1974; Schargel et al., 2005). Because of the key location, better knowledge of the herpetofauna of these mountains should contribute to an understanding of the evolutionary history of northern South America. Furthermore, the pressures of habitat destruction continue to impact this region dramatically. These effects are compounded by the observation that many of the known species of amphibians and reptiles are naturally highly restricted in distribution. This is particularly important for Turimiquire, which has been more impacted by varied anthropogenic activity (e.g., deforestation at all elevations, radio-communication activities, and agricul- ture in the main basin), yet receives little government protection (zona protectora Macizo del Turimiquire).

We fear that without expedient work, much of the unique herpetofauna of Turimiquire and the Peninsula de Paria will be lost before it can be properly assessed - such a loss would be highly lamentable. Anadia blakei has been included under the category of vulnerable in the third edition of the Libro Rojo de la Fauna Venezolana ("Red Book of the Venezuelan Fauna"), along with other reptiles endemic to the Turimiquire massif, such as Mabuya croizati and Atractus matthewi (Rivas et al., 2008).

At the moment only two species are endemic and present in the forest of both systems, namely Anadia blakei and an undescribed species of Gonatodes (Walter Schargel, personal commun.). Genera such as Riama, however, are represented by separate species in these two systems. Riama sp. is restricted to the Turimiquire summit above $2000 \mathrm{~m}$ (the maximum elevation on this mountain is $2400 \mathrm{~m}) ; R$. rhodogaster occurs in cloud forest of the Península de Paria near Las Melenas on the approach to Cerro Humo, at about $700 \mathrm{~m}$ elevation (the maximum elevation for the peninsula is $1371 \mathrm{~m}$ on Cerro Humo (Steyermark, 1973).

\section{NOTES ON HEMIPENIAL VARIATION IN THE GYMNOPHTHALMIDAE}

\section{INTRODUCTION}

Hemipenial morphology of the Gymnophthalmidae has taxonomic potential that was unexplored before the 1960s and 1970s, when Thomas Uzzell published a series of revisionary studies that included descriptions of uneverted hemipenes (especially Uzzell, 1973: 40-46). He removed, split open, and stained uneverted organs, showing that, in addition to various small spines, the hemipenes of many (most) microteiid genera have facing series of oblique or chevron-shaped flounces that bear comblike rows of calcareous spinules. The complex folding in the lobes at the tip of the uneverted hemipenis was, however, not amenable to study by dissection, and the spinule-bearing flounces on the body of organ were characterized as being in 
pouches or pockets. ${ }^{12}$ After inflated hemipenes became available, the spinule-bearing flounces could be seen as protruding from the surface of the everted organ (illustrations in: Donnelly et al., 1992: fig. 3; Harris and Ayala, 1987: fig. 6; Kizirian, 1995: fig. 4; 1996: figs. 6, 10, 19, 23; Kizirian and Coloma, 1991: fig. 2; Köhler and Lehr, 2004: figs. 3, 6, 9; Myers and Donnelly, 1996: fig. 20; 2008: figs. 57, 59; Presch, 1978: figs. $\left.1-8^{13}\right)$. But note that flounces lack spinules in some taxa (Harris, 1994: figs. 5, 14, 16, 17, 20, 24; Kizirian, 1996: 141).

Harris (1994: 228) studied some retracted gymnophthalmid hemipenes "by inverting them with forceps through a lengthwise incision made in the sulcus spermaticus." To carry that a step further, retracted gymnophthalmid hemipenes could be removed from preserved specimens, softened, manually everted, and inflated with petroleum jelly or other substance, following techniques used for squamates generally (e.g., see Myers and Cadle, 2003; Ziegler and Böhme, 1996). However, the spinulate flounces of gymnophthalmids such as Anadia blakei can be somewhat of an impediment to manual eversion (see page 23). Furthermore, many gymnophthalmids are very small lizards that have correspondingly tiny hemipenes, requiring care, steady hands, patience, and practice - the last not to be gained by dissection of unique specimens. Laboratory eversions of

\footnotetext{
12 The pouches or pockets noted by Uzzell presumably correspond to basinlike sections of the hemipenial wall that disappear owing to differential tissue expansion during eversion. They must not be confused with the "hemipenial pockets" characterizing some squamates. These retain identity in both retracted and everted states. ${ }^{13}$ Presch's (1978) figs. show some interesting configurations, but his drawings must be interpreted with caution. Some organs are incompletely everted, which led to serious misinterpretation in at least one case (Myers and Donnelly, 2001: 48, footnote 21). As used by Presch, "dorsal" and "ventral" sides of everted hemipenes are equivalent to asulcate and sulcate sides, respectively. Dorsal and ventral are appropriate descriptors for retracted hemipenes of squamates, but eversion sometimes is accompanied by notable changes in the relative positioning of various structures.

Presch's figs. 1-2 and associated description of Gymnophthalmus hemipenes deserve special note. The "elongated finger-like projections (villi)" and "fleshy protuberances" presumably are in some way homologous with the chevron-shaped folds of other gymnophthalmids, but their appearance is strikingly different.
}

retracted hemipenes from preserved specimens may have a smaller (less expanded) circumference than organs everted at time of death, but the terminal morphology can still be elucidated in ways not possible by dissection.

The published figures cited above were mostly of hemipenes everted at time of preservation, although in a few cases organs were softened in a solution of $\mathrm{KOH}$ and further inflated to test whether the apices had been fully everted. Unfortunately, collectors often fail to obtain complete eversions of gymnophthalmid hemipenes, most often perhaps because the retractor muscles are not sufficiently relaxed. The following field techniques are useful for field preparation of squamate hemipenes generally:

It is very useful and sometimes critically important for the muscles of the freshly-killed snake [or lizard] to become completely relaxed before injecting the tail base .... In order not to burst a small hemipenis nearing maximum inflation, a jeweler's loupe may be used to monitor the everting apex-in which case it is advisable to protect one's eyes by filling the syringe with water, which also will lessen skin exposure to formalin ... The initial use of water seems not to affect the subsequent formalin-fixation of delicate hemipenial tissue and may also minimize retraction or shrinkage of the retractor muscle .... [It is] particularly important that the retractor muscles be allowed to become completely relaxed after injection of diluted sodium pentobarbital (Nembutal) or other killing agent ... waiting the better part of an hour before everting hemipenes of rare [specimens] ... placing specimens, especially small ones, in a jar or plastic bag with some water or damp paper towels will prevent desiccation during the wait. (Myers and Cadle, 2003: 298)

Hemipenes everted completely (or nearly completely) in the field can later be prepared for study and illustration by techniques reviewed by Myers and Cadle (2003). Lizard and snake hemipenes occur in an extraordinary variety of shapes and sizes, and they continue to yield new morphological features of taxonomic interest. Although we speculate 
on the functional significance of some hemipenial structures, we recognize that we know very little about the actual shapes or degrees of expansion attained by hemipenes constrained within cloacae (the shapes of which also are subject to rarely analyzed interspecific and even intraspecific variation).

The following topics cover some aspects of hemipenial morphology that are relevant to gymnophthalmid systematics. Most character states cannot yet be adequately polarized.

\section{Comblike Spinulate Flounces}

Examination of specimens and published illustrations of gymnophthalmid hemipenes shows that the comblike rows of calcareous spinules occur in varying configurations that differ between species and probably genera. One difference involves presence or absence of a distinct set of medioproximal asulcate flounces (MPAF), which are short transverse or chevron-shaped spinulate plicae proximal to the median nude space ${ }^{14}$ on the asulcate side of the hemipenis. These plicae may connect laterally with other spinulate plicae or they may be separate, as in figure 15. They are shown as chevron shaped on retracted organs figured by Uzzell (e.g., 1973: 44, fig. 17), but shape conceivably changes to domelike or straight during eversion. In any case, the medioproximal asulcate flounces are transversely more or less straight in Anadia blakei (not illustrated in fig. 14), A. ocellata (fig. 15), and A. pamplonensis (Harris and Ayala, 1986, fig. 6).

The medioproximal asulcate flounces (MPAF) are shown on most gymnophthalmid hemipenes illustrated. They are slightly dome shaped in Cercosaura goeleti, but it is not certain that the MPAF are spinulate in this species (the other, chevron-shaped flounces of $C$. goeleti have minute spinules "embedded or feebly protruding at best" fide Myers and Donnelly, 1996: 29, fig. 20). Medioproximal asulcate flounces are lacking in some taxa, however, including Euspondylus auyanensis of this paper (fig. 6), Arthrosaura synaptolepis and A. montigena (Donnelly et al., 1992: fig. 3;

\footnotetext{
${ }^{14}$ The median nude space of the asulcate side of the hemipenis was termed "median welt" by Uzzell because of its appearance in the retracted hemipenis. It expands to smooth tissue on eversion.
}

Myers and Donnelly, 2008: fig. 57), and Neusticurus rudis (Myers and Donnelly, 2008: fig. 59).

\section{Morphology of Bilobed Section}

Many (if not most) gymnophthalmids have bilobed hemipenes. Uzzell (1973: 40-41) understandably "placed little emphasis on variation" in the complex folding of the retracted lobes. Indeed, the apices of the lobes are often difficult to interpret even when inflated, in part because it may be impossible to determine whether the tiny lobes are completely everted (especially when one is preparing a specimen under field conditions!).

Nonetheless, the lobes and intervening crotch are a rich source of characters and are worth detailed attention, as shown by the following examples. In Arthrosaura synaptolepis the lobes are terminally flattened, with disclike apices and, in the crotch, a pronounced bumplike structure marking the division of the sulcus spermaticus (Donnelly et al., 1992: fig. 3). In contrast, A. montigena has flounces of comblike spinulate flounces extending well onto the (fully everted?) lobes and there is a distinct, relatively deep hole (the "orificium") in the lobular crotch (Myers and Donnelly, 2008: 96, fig. 57). Raised tissue at the sulcus division seems not uncommon on gymnophthalmid hemipenes, but the orificium, as interpreted, is a seemingly unique structure among lizards and snakes.

As shown in many illustrations, the everted apices of gymnophthalmid hemipenes often seem to be complexly and very irregularly folded, but this bears close consideration. If the lobes are fully inflated, some pattern may be discernible in the folding and orientation of the sulcus spermaticus (itself often broad and indistinctly bifurcated). An example is provided by the new Euspondylus auyanensis, which at first glance seemed to have commonplace lobes terminating in folds resembling little hills and valleys. The sulcate face of each lobe, however, bears an easily overlooked, shallow rimmed space or "basin," here interpreted as a possible concentration area for seminal fluid (figs. 6-7 and associated text).

The sulcus spermaticus normally bifurcates at the median crotch. The course of the two 
branches is not always obvious, although the tissue floor is usually smooth, flat, and unmarked. The sulcus branches of Anadia blakei, however, are unusually wide and bear a cross-lined pattern of minute ridges. Seminal fluid presumably flows into facing cuplike depressions near the tips of the lobes (fig. 14), very different in position from the concentration areas suggested above for Euspondylus auyanensis and below for Anadia ocellata.

\section{Nonspinulate "Nude" Hemipenes}

The genera Alopoglossus, Ptychoglossus, Adercosaurus, and Ecpleopus have spineless hemipenes (see also Neusticurus below). The asulcate sides of the organs of the first three genera bear nonspinulate tissue ridges or flounces that are transversely aligned or dome shaped (rather than oblique and chevron shaped). In Ecpleopus, however, even the flounces are lacking (Uzzell, 1969: 8, fig. 3).

Harris (1994: 272) observed that the hemipenis of Ptychoglossus "has [nonspinulate] flounces of the form found in macroteiids and the closely related Alopoglossus, a primitive condition among microteiids." Based on this and other aspects of morphology, Harris suggested that these two genera possibly comprise a sister group to all other microteiids. Harris' hypothesis was not cited but was nonetheless corroborated by subsequent molecular analyses. Pellegrino et al. (2001) found Alopoglossus to be the sister taxon to all other gymnophthalmids and erected the subfamily Alopoglossinae for it. Castoe et al. (2004) corrected an error in the Pellegrino et al. data set and added Ptychoglossus to the Alopoglossinae.

Castoe et al. (2004: 465) were "unable to place Adercosaurus Myers and Donnelly, 2001, definitively in a subfamily because we were unable to examine specimens [the unique specimen had been transferred from AMNH to EBRG in Venezuela] ... this genus may belong in the Alopoglossinae, the Ecpleopinae, or the Cercosaurini." However, the Cercosaurini can be reasonably excluded because Adercosaurus lacks oblique or chevron-shaped spinulate flounces; the nonspinulate flounces are transversely dome shaped (Myers and Donnelly, 2001: fig. 39).
Various genera in the classifications of Pellegrino et al. (2001) and Castoe et al. (2004) lack DNA data and are provisionally placed to subfamily based on resemblances or previous associations. We therefore feel no restraint in provisionally assigning Adercosaurus to the Alopoglossinae because of its hemipenial, lingual, and physiognomic resemblances to Ptychoglossus.

The recently described Kaieteurosaurus Kok (2005) from Guyana is another monotypic genus known from a single (female) specimen. Although differing in significant features of scutellation, Kaieteurosaurus shares with Adercosaurus and Riolama remarkable resemblances in dorsal tongue morphology (anterior and posterior plicae separated by median section of scalelike papillae) and ventral coloration (dark or dark-edged ventral scales with pale centers). We suspect that Riolama is currently misplaced in the Cercosaurini and that molecular and hemipenial data will eventually confirm that both it and Kaieteurosaurus belong with Adercosaurus in the Alopoglossinae. However, the lingual morphology of Adercosaurus, Kaieteurosaurus, and Riolama is shared by Ecpleopus (Ecpleopinae), which also shares with Kaieteurosaurus the unusual gymnophthalmid condition of hexagonal ventral scales. Adercosaurus, Kaieteurosaurus, and Riolama are genera endemic to the western part of the Guayana (Guiana) Shield, whereas Ecpleopus is endemic to the Brazilian Shield. It remains to be determined whether the complete lack of flounces on the nude hemipenis of Ecpleopus is primitive or derived.

\section{COMMENTS ON NEUSTICURUS}

The genus Neusticurus sensu stricto (fide Doan and Castoe, 2005: 409-411) is excluded from the above category of genera characterized by nonspinulate "nude" hemipenes - even though it is thought to lack calcareous spinules on the flounces. Most or all the five species (bicarinatus, medemi, racenisi, rudis, tatei) currently included in Neusticurus have very welldeveloped flounces that are similar in outward appearance to those of most other gymnophthalmids. The flounces, which are reflexed into typical chevron shapes, contain "denser 

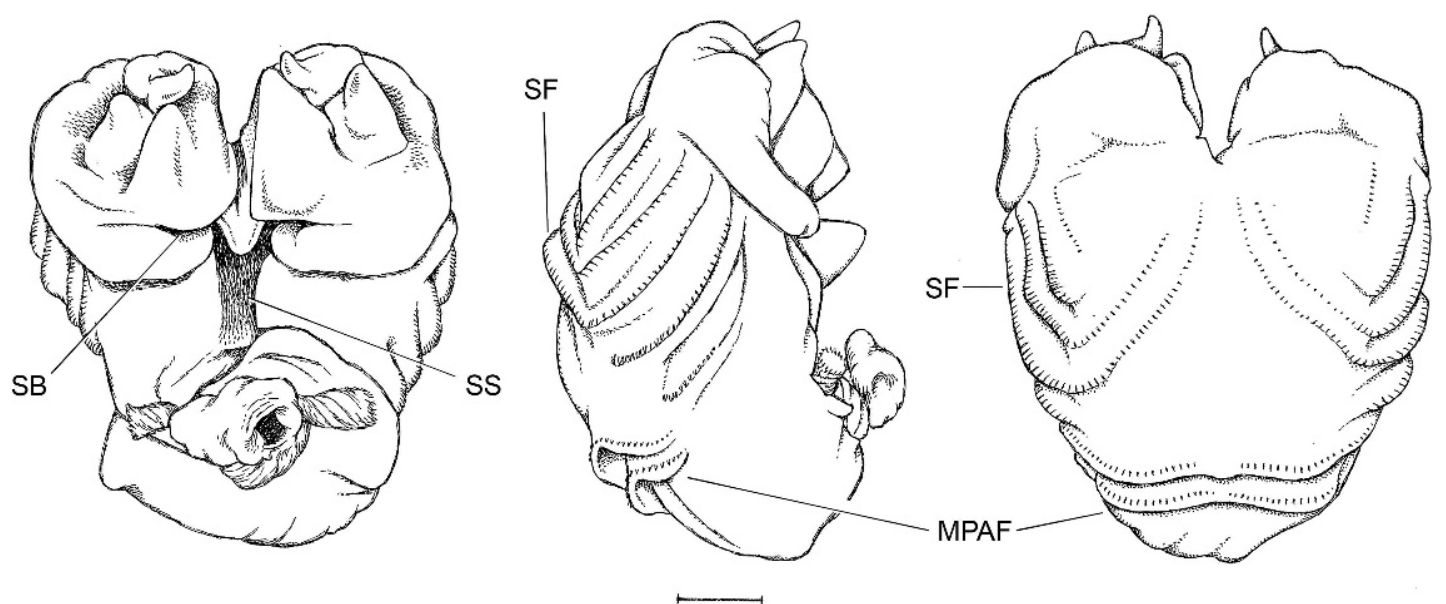

Fig. 15. Hemipenis of Anadia ocellata. Field-everted left organ of AMNH R-129779. Left: sulcate side. Center: lateral view, turned with sulcate side facing to right. Right: asulcate side. MPAF, medioproximal asulcate spinulate flounces; SB, branch of sulcus spermaticus; SF, spinulate flounces; SS, sulcus spermaticus. Scale line $=1 \mathrm{~mm}$.

supporting areas" (fide Uzzell, 1966: 311, for bicarinatus, rudis, and tatei). According to Uzzell, the supporting structures of the flounces (sometimes irregularly shaped) do not stain with alizarin red $\mathrm{S}$.

A simple loss of calcification as an evolutionary event seems likely to have occurred if the supporting structures are homologous with calcareous spinules, which looks to be the case with Neusticurus rudis. Myers and Donnelly (2008: 99) described and illustrated the hemipenis of $N$. rudis as having comblike rows of "minute, presumably mineralized spinules," but the tiny spinulelike structures indicated in their illustration (of the left organ from AMNH R-140208) appear noncalcareous after staining with alizarin red $\mathrm{S}$ in 2009 (following the method of Uzzell, 1973: 40-41).

\section{Hemipenis of ANADIA OCELLATA}

The organ illustrated in figure 15 shows several hemipenial features mentioned above. The left field-everted hemipenis of AMNH R129779 is a tiny bilobed organ $6 \mathrm{~mm}$ long in sulcate view and $5 \mathrm{~mm}$ across. Owing to differential tissue expansion during eversion, the severed end lies not at the proximal base but higher on the sulcate side. An everted left organ from a second specimen (AMNH R-
114306) is very similar but slightly less inflated. Both specimens are from western Panama.

There are three stout, soft-tissue papillae atop each lobe; the medially positioned papilla has an elongated crested apex, paralleling the one on the opposite lobe. The sulcus spermaticus bifurcates at a ridge of raised tissue in the crotch. Each sulcus branch turns sharply laterad, running a short course up onto a broad collar flanking the sulcate sides of the apical papillae. Seminal fluid conceivably pockets in a deep depression surrounding the lateralmost papilla (suggested especially by the appearance of the less fully inflated hemipenis from AMNH R-114306).

There are several chevron-shaped flounces on the asulcate side below each lobe and, below those, two additional oblique flounces positioned more laterally. There are two transversely aligned, very pronounced medioproximal asulcate flounces that do not connect with the single lateral flounces.

The two organs discussed above are the ones mentioned by Myers and Donnelly (2001: 49) as falsifying Presch's (1978: fig. 6) description of a bulbous, nonlobed nude hemipenis. The latter (under the synonymous name $A$. metallica) appears to have been the proximal part of an incompletely everted organ. 


\section{ACKNOWLEDGMENTS}

We thank Annemarie Ohler and Ivan Ineich for lending the Paris Museum (MNHN) holotype of Euspondylus auyanensis. We are grateful to Renaud Boistel for supplying information about its capture and to JeanChristophe de Massary for his photographs of the living animal. Rivas owes special thanks to Aurélien and Bérengère Miralles, for the hospitality in their home in Paris in 2005, during his visit to MNHN, where he first saw the specimen herein designated as holotype.

For use of other specimens and information, we sincerely thank Francisco J. Bisbal, Director, and Ramón Rivero, Curator of Reptiles, Museo de la Estación Biológica de Rancho Grande (EBRG), Maracay. The EBRG specimen of Anadia escalerae was first called to Myers' attention by Alfredo Paolillo O.; it was collected by John E. Cadle, who kindly provided locality information and photographs of habitat. Francisco J. Bisbal and Javier H. Sánchez provided photographs of the holotype of Anadia pariaensis for comparison. Alan Resetar sent photographs of the holotype of Anadia blakei from the Field Museum of Natural History.

Facilities and support for Rivas to work in the Amphibian and Reptile Diversity Research Center (fall 2007-spring 2008) were provided by Eric N. Smith and Jonathan A. Campbell, through a student/exchange visitor program, University of Texas at Arlington; this program was supported by grants to Eric N. Smith from the National Science Foundation (DEB0416160) and Instituto Bioclon, Mexico.

Myers' recent work has been supported by Robert G. Goelet, former president and Chairman Emeritus of the Board of Trustees of the American Museum of Natural History. This paper is a follow-up to a report on the Robert G. Goelet American Museum-TERRAMAR Expedition to Auyantepui (Myers and Donnelly, 2008). Photographs other than acknowledged in captions were taken by Peter Goldberg. The pen-and-ink drawings were executed by Patricia J. Wynne. We are especially grateful to gymnophthalmid specialists Tiffany M. Doan, David A. Kizirian, Dennis M. Harris, and Thomas Uzzell, who generously took time to read the manuscript and share their expertise.

\section{REFERENCES}

Allen, Joel A. 1900. On mammals collected in southeastern Peru, by Mr. H.H. Keays, with descriptions of new species. Bulletin of the American Museum of Natural History 13(18): 219-227.

Allen, Joel A. 1901. On a further collection of mammals from southeastern Peru, collected by Mr. H.H. Keays, with descriptions of new species. Bulletin of the American Museum of Natural History 14(3): 41-46.

Ayarzagüena, José, J. Celsa Señaris, and Stefan Gorzula. 1992. El grupo Osteocephalus rodriguezi de las tierras altas de la Guayana venezolana: descripción de cinco nuevas especies. Memoria / Sociedad de Ciencias Naturales La Salle 137: 113-142.

Bauer, Aaron M., Rainer Günther, and Meghan Klipfel. 1995. The herpetological papers of Wilhelm C.H. Peters. Ithaca, NY: Society for the Study of Amphibians and Reptiles, Facsimile Reprints in Herpetology, 714 pp.

Boulenger, George Albert. 1885. Catalogue of the lizards in the British Museum (Natural History). 2nd ed. Vol. 2: xiii, 497 pp. +24 pls.

Castoe, Todd A., Tiffany M. Doan, and Christopher L. Parkinson. 2004. Data partitions and complex models in Bayesian analysis: the phylogeny of Gymnophthalmid lizards. Systematic Biology 53(3): 448-469.

Doan, Tiffany M., and Todd A. Castoe. 2005. Phylogenetic taxonomy of the Cercosaurini (Squamata: Gymnophthalmidae), with new genera for species of Neusticurus and Proctoporus. Zoological Journal of the Linnean Society 143(3): 405-416.

Donnelly, Maureen A., Roy W. McDiarmid, and Charles W. Myers. 1992. A new lizard of the genus Arthrosaura (Teiidae) from southern Venezuela. Proceedings of the Biological Society of Washington 105(4): 821-833.

Duellman, William E. 1997. Amphibians of La Escalera region, southeastern Venezuela: taxonomy, ecology, and biogeography. Scientific Papers Natural History Museum the University of Kansas 2: 1-52.

Dunn, Emmett Reid 1942. The American caecilians. Bulletin of the Museum of Comparative Zoology 91(6): 439-540.

Dunsterville, G.C.K. 1965. Auyantepui. Boletin de la Sociedad Venezolana de Ciencias Naturales 26(109): 163-171 + 2 foldout maps.

Gorzula, Stefan. 1992. La herpetofauna del macizo del Chimantá. In O. Huber (editor), El macizo del Chimantá. Caracas: 267-280 + 304-310 (photographs 152-171). Oscar Todtmann Editores. 
Gorzula, Stefan, and J. Celsa Señaris. 1999. Contribution to the herpetofauna of the Venezuelan Guayana I: a data base. Scientia Guaianae: 8, xviii, 268 pp. + 129 color photos [in 32 end pls.], maps $2-5$ in pocket ("1998" on cover, but explicitly January 20, 1999 on verso of inside title page).

Harris, Dennis M. 1985. Infralingual plicae: support for Boulenger's Teiidae (Sauria). Copeia 1985(3): 560-565.

Harris, Dennis M. 1994. Review of the teiid lizard genus Ptychoglossus. Herpetological Monographs 8: 226-275.

Harris, Dennis M., and Stephen A. Ayala. 1987. A new Anadia (Sauria: Teiidae) from Colombia and restoration of Anadia pamplonensis Dunn to species status. Herpetologica 43(2): 182-190.

Kizirian, David A. 1995. A new species of Proctoporus (Squamata: Gymnophthalmidae) from the Andean Cordillera Oriental of northeastern Ecuador. Journal of Herpetology 29(1): 66-72.

Kizirian, David A. 1996. A review of Ecuadorian Proctoporus (Squamata: Gymnophthalmidae) with descriptions of nine new species. Herpetological Monographs 10: 85-155.

Kizirian, David A., and Luis A. Coloma. 1991. A new species of Proctoporus (Squamata: Gymnophthalmidae) from Ecuador. Herpetologica 47(4): 420-429.

Köhler, Gunther, and Edgar Lehr. 2004. Comments on Euspondylus and Proctoporus (Squamata: Gymnophthalmidae) from Peru, with the description of three new species and a key to the Peruvian species. Herpetologica 60(4): 501-518.

Kok, Philippe J.R. 2005. A new genus and species of gymnophthalmid lizard (Squamata: Gymnophthalmidae) from Kaieteur National Park, Guyana. Bulletin de l'Institut Royal des Sciences Naturelles de Belgique Biologie 75: 35- 45 .

Lindorf, Helga. 2006. La expedición universitaria a la meseta Auyán-tepui, abril 1956. Acta Botánica Venezuelica 29(1): 177-188.

Mijares-Urrutia, Abraham, J. Celsa Señaris, and Alexis Arends. 2000. Taxonomía de algunos microtéidos (Squamata) de Venezuela, I: Variación y distribución geográfica de Euspondylus acutirostris y descripción de un nuevo Euspondylus del nordeste de Venezuela. Revista de Biología Tropical 48(2-3): 671-680.

Montero, Ricardo, Silvia Alejandra Moro, and Virginia Abdala. 2002. Cranial anatomy of Euspondylus acutirostris (Squamata: Gymnophthalmidae) and its placement in a modern phylogenetic hypothesis. Russian Journal of Herpetology 9(3): 215-228.

Myers, Charles W. 1997. Preliminary remarks on the summit herpetofauna of Auyantepui, eastern Venezuela. Acta Terramaris 10: 1-8.
Myers, Charles W., and John E. Cadle. 2003. On the snake hemipenis, with notes on Psomophis and techniques of eversion: a response to Dowling. Herpetological Review 34(4): 295-302.

Myers, Charles W., and Maureen A. Donnelly. 1996. A new herpetofauna from Cerro Yaví, Venezuela: first results of the Robert G. Goelet American Museum-Terramar Expedition to the northwestern tepuis. American Museum Novitates 3172: 1-56.

Myers, Charles W., and Maureen A. Donnelly. 2001. Herpetofauna of the Yutajé-Corocoro massif, Venezuela: second report from the Robert G. Goelet American MuseumTERramar Expedition to the northwestern tepuis. Bulletin of the American Museum of Natural History 261: 1-85.

Myers, Charles W., and Maureen A. Donnelly. 2008. The summit herpetofauna of Auyantepui, Venezuela: report from the Robert G. Goelet American Museum-Terramar Expedition. Bulletin of the American Museum of Natural History 308: 1-147.

Oftedal, Olav T. 1974. A revision of the genus Anadia (Sauria, Teiidae). Arquivos de Zoologia (São Paulo) 25(4): 203-265.

Pellegrino, Katia C.M., Miguel T. Rodrigues, Y. Yonenaga-Yassuda, and Jack W. Sites, Jr. 2001. A molecular perspective on the evolution of microteiid lizards (Squamata, Gymnophthalmidae), and a new classification for the family. Biological Journal of the Linnean Society 74(3): 315-338.

Peters, James A., and Roberto Donoso-Barros. 1970. Catalogue of the Neotropical Squamata. Part II. Lizards and amphisbaenians. United States National Museum Bulletin 297: viii, 1-293.

Peters, Wilhelm. "1862" [1863]. Über Cercosaura und die mit dieser Gattung verwandten Eidechsen aus Südamerica. Abhandlungen der Königlichen Akademie der Wissenschaften zu Berlin 1862: 165-225 + 3 pls. [Usually dated "1862," but see Bauer et al., 1995: 22].

Presch, William. 1978. Descriptions of the hemipenial morphology in eight species of microteiid lizards (family Teiidae, subfamily Gymnophthalminae). Herpetologica 34(1): 108-112.

Presch, William. 1983. The lizard family Teiidae: is it a monophyletic group? Zoological Journal of the Linnean Society 77(2): 189-197.

Rivas, Gilson, and Oswaldo Oliveros. 1997. Herpetofauna del estado Sucre, Venezuela: lista preliminar de reptiles. Memoria de la Sociedad de Ciencias Naturales La Salle 147: 67-80.

Rivas, Gilson, Enrique La Marca, and Oswaldo Oliveros. 1999. Una nueva especie de Anadia (Reptilia: Gymnophthalmidae) del noreste de 
Venezuela. Acta Biológica Venezuelica 19(4): $27-32$.

Rivas, Gilson, Fernando Rojas-Runjaic, and César R. Molina. 2008. Anadia del Turimiquire, Anadia blakei. In J.P. Rodríguez and F. Rojas-Suárez (editors), Libro rojo de la fauna Venezolana. 3rd ed. Caracas: Provita y Shell Venezuela S.A, 179 pp.

Schargel, Walter E., Gilson Rivas Fuenmayor, and Charles W. Myers. 2005. An enigmatic new snake from cloud forest of the Península de Paria, Venezuela (Colubridae: Genus Taeniophallus?). American Museum Novitates 3484: $1-22$.

Schmidt, Karl P. 1932. Reptiles and amphibians of the Mandel Venezuelan Expedition. Field Museum of Natural History, Zoological Series 18(7): 159-163.

Stephens, Lorain, and Melvin A. Traylor, Jr. 1983. Ornithological gazetteer of Peru. Cambridge, MA: Museum of Comparative Zoology, vi, $271 \mathrm{pp.}$

Steyermark, Julian A. 1967. Flora del Auyan-tepui. Acta Botánica Venezuelica 2(5-8): 5-370.

Steyermark, Julian A. 1973. Preservemos las cumbres de la Península de Paria. Defensa de la Naturaleza 2(6): 33-35.
Steyermark, Julian A. 1974. Relación florística entre la Cordillera de la Costa y la zona de Guayana y Amazonas. Acta Botánica Venezuelica 9(1-4): 245-252.

Uzzell, Thomas. 1966. Teiid lizards of the genus Neusticurus (Reptilia, Sauria). Bulletin of the American Museum of Natural History 132(5): 277-327.

Uzzell, Thomas. 1969. The status of the genera Ecpleopus, Arthroseps and Aspidolaemus (Sauria, Teiidae). Postilla 135: 1-23.

Uzzell, Thomas. 1970. Teiid lizards of the genus Proctoporus from Bolivia and Peru. Postilla 142: 1-39.

Uzzell, Thomas. 1973. A revision of lizards of the genus Prionodactylus, with a new genus for $P$. leucostictus and notes on the genus Euspondylus (Sauria, Teiidae). Postilla 159: 1-67.

Vaurie, Charles. 1972. An ornithological gazetteer of Peru: based on information supplied by J.T. Zimmer. American Museum Novitates 2491: $1-36$.

Ziegler, Thomas, and Wolfgang Böhme. 1996. Zur Hemiclitoris der squamaten Reptilien: Auswirkungen auf einige Methoden der Geschlechtsunterscheidung. Herpetofauna 18(101): 11-19. 
Complete lists of all issues of the Novitates and the Bulletin are available at World Wide Web site http://library.amnh.org/pubs. Inquire about ordering printed copies via e-mail from scipubs@amnh.org or via standard mail from: American Museum of Natural History, Library-Scientific Publications, Central Park West at 79th St., New York, NY 10024. TEL: (212) 769-5545. FAX: (212) 769-5009. 